\title{
DNA-PKcs, ATM, and ATR Interplay Maintains Genome Integrity during Neurogenesis
}

\author{
Vanessa Enriquez-Rios, ${ }^{1,2 *}$ Lavinia C. Dumitrache, ${ }^{1 *}$ (D) Susanna M. Downing, ${ }^{1 *}$ Yang Li, ${ }^{1}$ Eric J. Brown, ${ }^{3}$ \\ Helen R. Russell, ${ }^{1}$ and Peter J. McKinnon ${ }^{1,2}$ \\ ${ }^{1}$ Department of Genetics, St Jude Children's Research Hospital, Memphis, Tennessee 38105, ${ }^{2}$ College of Graduate Health Sciences, University of Tennessee \\ Health Science Center, Memphis, Tennessee 38163, and ${ }^{3}$ Abramson Family Cancer Research Institute and the Department of Cancer Biology, Perelman \\ School of Medicine, University of Pennsylvania, Philadelphia, Pennsylvania 19104
}

The DNA damage response (DDR) orchestrates a network of cellular processes that integrates cell-cycle control and DNA repair or apoptosis, which serves to maintain genome stability. DNA-PKcs (the catalytic subunit of the DNA-dependent kinase, encoded by $P R K D C$ ), ATM (ataxia telangiectasia, mutated), and ATR (ATM and Rad3-related) are related PI3K-like protein kinases and central regulators of the DDR. Defects in these kinases have been linked to neurodegenerative or neurodevelopmental syndromes. In all cases, the key neuroprotective function of these kinases is uncertain. It also remains unclear how interactions between the three DNA damageresponsive kinases coordinate genome stability, particularly in a physiological context. Here, we used a genetic approach to identify the neural function of DNA-PKcs and the interplay between ATM and ATR during neurogenesis. We found that DNA-PKcs loss in the mouse sensitized neuronal progenitors to apoptosis after ionizing radiation because of excessive DNA damage. DNA-PKcs was also required to prevent endogenous DNA damage accumulation throughout the adult brain. In contrast, ATR coordinated the DDR during neurogenesis to direct apoptosis in cycling neural progenitors, whereas ATM regulated apoptosis in both proliferative and noncycling cells. We also found that ATR controls a DNA damage-induced $\mathrm{G}_{2} / \mathrm{M}$ checkpoint in cortical progenitors, independent of ATM and DNA-PKcs. These nonoverlapping roles were further confirmed via sustained murine embryonic or cortical development after all three kinases were simultaneously inactivated. Thus, our results illustrate how DNA-PKcs, ATM, and ATR have unique and essential roles during the DDR, collectively ensuring comprehensive genome maintenance in the nervous system.

Key words: ATM; ATR; DNA damage; DNA-Pkcs; genome stability; neurogenesis

\section{Significance Statement}

The DNA damage response (DDR) is essential for prevention of a broad spectrum of different human neurologic diseases. However, a detailed understanding of the DDR at a physiological level is lacking. In contrast to many in vitro cellular studies, here we demonstrate independent biological roles for the DDR kinases DNA-PKcs, ATM, and ATR during neurogenesis. We show that DNA-PKcs is central to DNA repair in nonproliferating cells, and restricts DNA damage accumulation, whereas ATR controls damage-induced $\mathrm{G}_{2}$ checkpoint control and apoptosis in proliferating cells. Conversely, ATM is critical for controlling apoptosis in immature noncycling neural cells after DNA damage. These data demonstrate functionally distinct, but cooperative, roles for each kinase in preserving genome stability in the nervous system.

\section{Introduction}

Maintaining genomic integrity in the developing and mature nervous system is essential to prevent neurologic disease (Barzilai, 2013;
McKinnon, 2013; Madabhushi et al., 2014). There are many sources of endogenous DNA damage. For instance, replication-associated DNA damage during neurogenesis is frequent, and reactive 
byproducts of metabolism or transcriptionassociated DNA damage are also a constant threat to genome integrity (Aguilera and García-Muse, 2012; McKinnon, 2013). To ensure normal neural development, there is a broad armamentarium of DNA damage response factors that can correct multiple types of common endogenous DNA lesions.

Several key protein kinases respond to specific types of DNA lesions to activate signaling cascades that coordinate the DNA damage response (DDR). DNAPKcs (encoded by PRKDC), ATM, and ATR are related phosphatidylinositol-3kinase-like serine/threonine kinases that can initiate cell cycle arrest, DNA repair, or apoptosis (Lavin, 2008; McKinnon, 2012; Shiloh and Ziv, 2013). The activation of individual kinases is linked to the type of DNA lesion generated. For example, DNA-PKcs is recruited to doublestrand breaks (DSBs) by the heterodimer complex $\mathrm{Ku} 70 / 80$ to form the holoenzyme DNA-PK and facilitate DNA repair via nonhomologous end-joining (NHEJ), a main DNA repair pathway for DSBs in mammalian cells (Lieber, 2010; Chapman et al., 2012; Davis and Chen, 2013; Jette and Lees-Miller, 2015). Compared with core NHEJ components, such as Ku70/80, XRCC4, or DNA Ligase IV (LIG4), which lead to widespread neural apoptosis and embryonic lethality, or compromised development when inactivated, mice lacking DNA-PKcs are viable (Gu et al., 2000; Douglas et al., 2005). Consequently, DNA-PKcs function during neurogenesis in the context of DNA damage and NHEJ remains uncertain. Additionally, DNAPKcs has also been linked to processes outside of NHEJ, such as transcription regulation, including the response to insulin (Wong et al., 2009; Goodwin and Knudsen, 2014).

ATM can be activated by DNA DSBs and is recruited to this damage by the MRN (Mre11/Rad50/Nbs1) complex to signal cell cycle arrest, facilitate DNA repair, or activate apoptosis in immature neural cells (Shull et al., 2009; Stracker and Petrini, 2011; Marechal and Zou, 2013; Paull, 2015). In contrast, ATR is activated by replication protein-A bound single-stranded DNA generated by MRN-mediated resection of breaks (Nam and Cortez, 2011; Marechal and Zou, 2013). Both ATM and ATR have also been ascribed roles not reflective of DNA damage signaling, including synaptic vesicular function and autophagy (Li et al., 2009; Tripathi et al., 2016). Loss of ATM can result in the neurodegenerative syndrome ataxia telangiectasia, and hypomorphic ATR mutation the neurodevelopmental disorder ATR-Seckel syndrome (O'Driscoll et al., 2004; McKinnon, 2012). PRKDC mutations have been identified in two immune-compromised individuals associated with microcephaly (van der Burg et al., 2009; Woodbine et al., 2013).
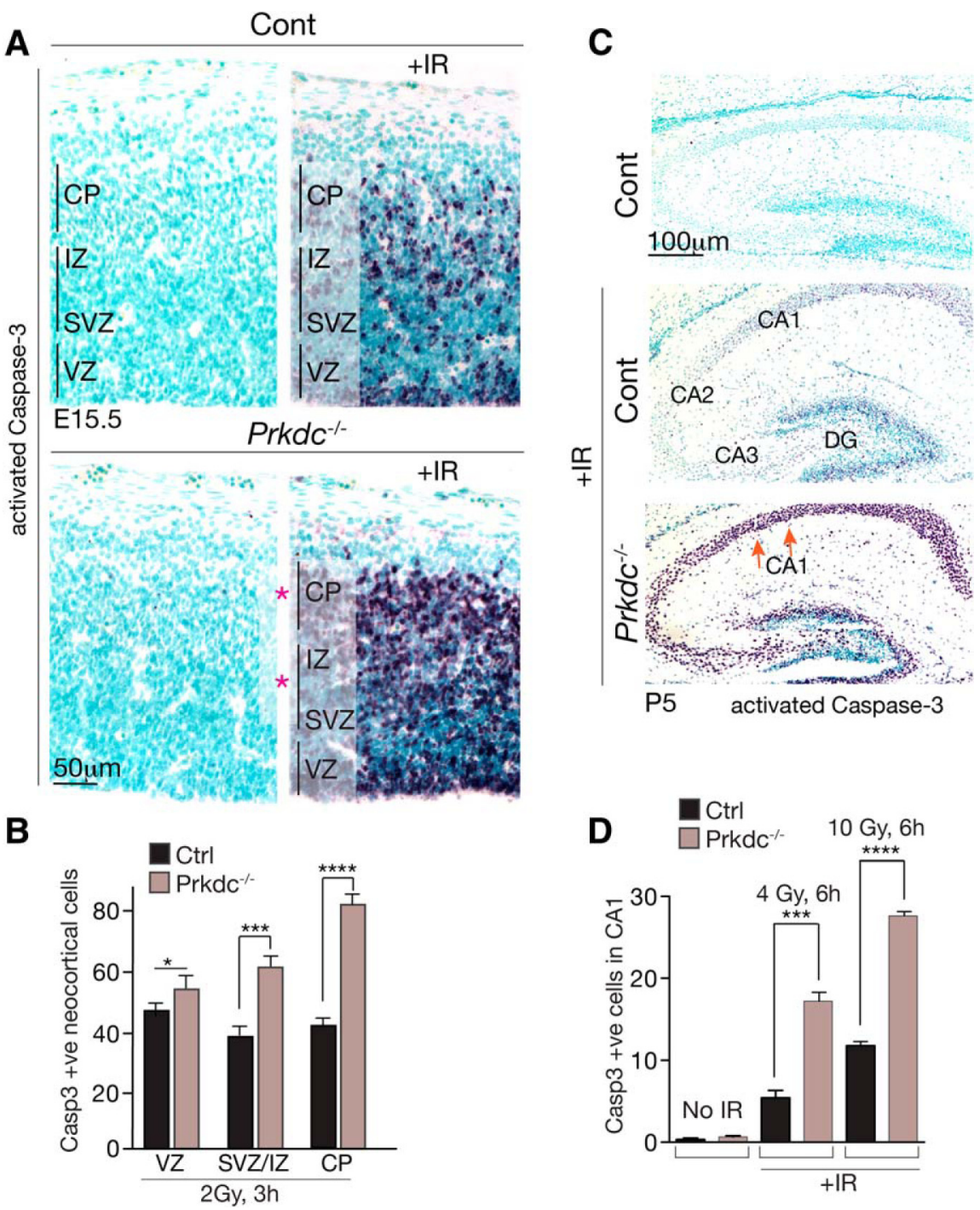

Figure 1. DNA-PKcs is neuroprotective in the developing cortex. $A$, Immunohistochemical identification of activated caspase-3 in E15.5 sagittal sections of murine neocortex shows increased apoptosis in the Prdkc ${ }^{-1-}$ tissue $3 \mathrm{~h}$ after $2 \mathrm{~Gy}$ of IR. Red asterisks indicate regions of the Prdkc ${ }^{-1-}$ neocortex associated with increased apoptosis. Sections were counterstained with methyl green. Vertical lines indicate regions that were quantified. $\boldsymbol{B}$, Increased apoptosis in the Prkdc ${ }^{-/-}$neocortex occurs in all areas, but there are quantitative differences related to the specific stage of neuronal differentiation. The VZ shows the smallest difference $\left({ }^{*}<0.05\right)$, with a more significant increase seen in the combined SVZ/IZ ( $\left.{ }^{* * *} p<0.001\right)$; the most significant increase $\left({ }^{* * *} p<\right.$ 0.0001 ) in activated caspase-3 staining was found in the immature noncycling cells of the developing (P. C, Sagittal sections of the P5 postnatal Prdkc ${ }^{-1-}$ hippocampus showed significantly enhanced levels of apoptosis after IR in the CA and the DG regions is associated with significant dose-dependent increases in apoptosis compared with WT tissue. Graphs represent mean values of replicates ( $n=3$ animals per group). Error bars indicate SEM.

How these three kinases collectively coordinate the responses to DNA damage within a physiological context remains unclear. It has been suggested that redundancy exists between these kinases, as they can phosphorylate similar substrates (e.g., p53) and dual loss of ATM and DNA-PKcs results in synthetic lethality (Gurley and Kemp, 2001; Matsuoka et al., 2007; Lavin, 2008; Bensimon et al., 2010). Here, we show that during neurogenesis DNA-PKcs functions to maintain genome integrity in the nervous system in a complementary manner to ATM and ATR, with each kinase fulfilling distinct and separate roles. Collectively, our data reveal both new insights into DNA-PKcs function and how these important DNA damage-responsive kinases cooperatively maintain genomic integrity in the nervous system. 
A

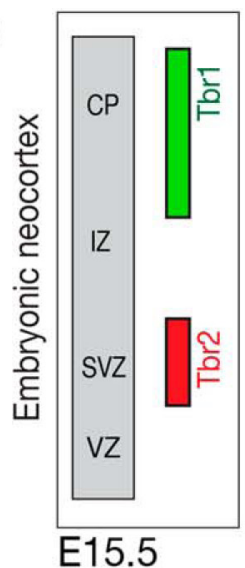

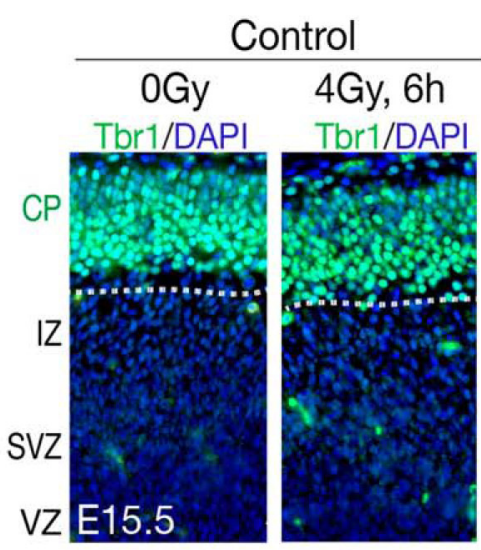

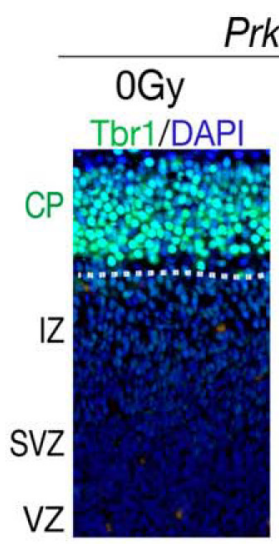

Prkdc $^{-1-}$
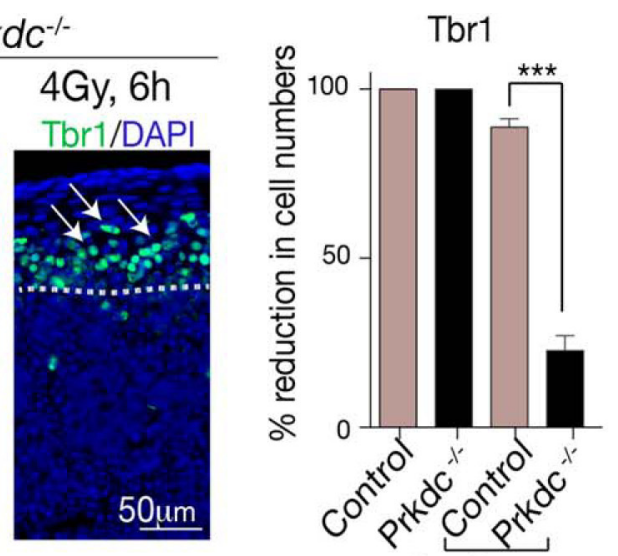

4Gy, 6 h recov
B

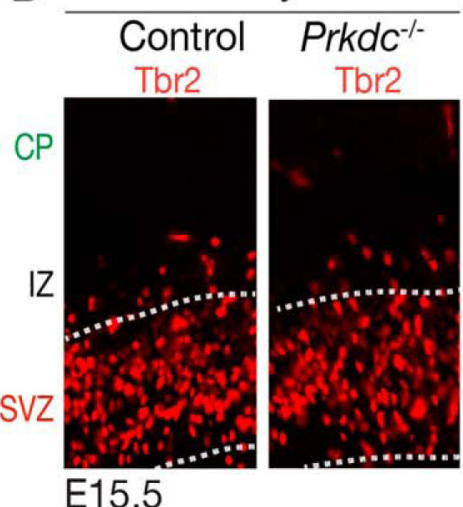

4Gy, $6 \mathrm{~h}$

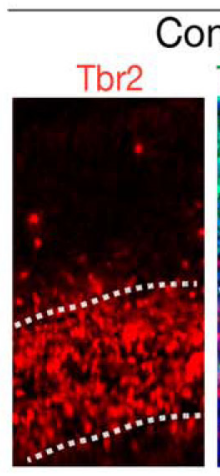

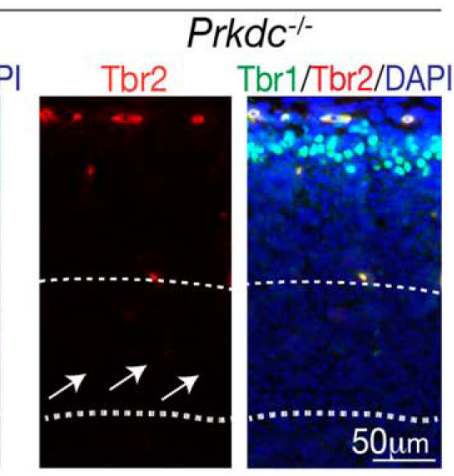

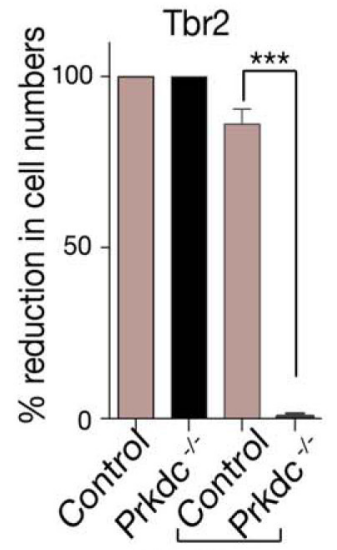

4Gy, 6h recov

Figure 2. DNA-PKcs loss selectively sensitizes cortical regions to DNA damage during development. $A$, Immunohistochemistry of sagittal E15.5 embryonic cortex using antibodies that recognize Tbr1 and Tbr2 distinguish different cortical regions, as shown in the illustration. Numbers of Tbr $1^{+}$neural progenitors are similar between E15.5 WT and Prdkc ${ }^{-1-}$ unirradiated neocortex. After radiation, there is a marked reduction in $\mathrm{Tbr}^{+}{ }^{+}$cells in the Prdkc ${ }^{-{ }^{-}}$tissue compared with WT, revealing hypersensitivity in the CP to DNA-PKcs loss. $\boldsymbol{B}$, Tbr2 ${ }^{+}$cells are also hypersensitive in the $\mathrm{Prdkc}^{-{ }^{-}}$neocortex, with a loss of this population $6 \mathrm{~h}$ after radiation. Quantification of IR-induced cell loss in the Tbr ${ }^{+}$and Tbr2 ${ }^{+}$neocortical cell populations shows a significant loss of both $\mathrm{Tbr}^{+}{ }^{+}$and Tbr2 ${ }^{+}$cells in the Prdkc ${ }^{-1-}$ CP. ${ }^{* * *} p<0.0001$.

\section{Materials and Methods}

Animals. Atm, $p 53$, and Atr mice and genotyping have been described previously (Lee et al., 2012). Prkdc mice (Gao et al., 1998a) were genotyped by PCR using the following primers: wild-type alleles were amplified with forward primer 5' -TGACAGCAAGTGCCTGTAAAGTGC and reverse primer 5'-ATAGTCCCTTCAGACAGCCAGC; and the Prkdc null allele was identified using reverse primer $5^{\prime}$-GAAGCGGGAAGGGACTGGCTGCTA (in lines with no cre) or 5'-CGCAGCGCATCGCCTTCTATCGCC (in lines with cre) and the same forward primer as the wild-type allele. Nestin-cre and Emx1-cre mice were obtained from The Jackson Laboratory (JAX mouse identifier \#003771, RRID:IMSR_JAX:003771 and \#005628, RRID:IMSR_ JAX:005628). Mice of either sex were used for experiments, although when possible littermates were sex-matched. All animals were maintained in an Association for Assessment and Accreditation of Laboratory Animal Careaccredited facility, and the Institutional Institutional Animal Care and Use Committee approved all experiments.

Histology. Mice were perfused transcardially with $4 \%$ PFA while embryos were drop-fixed in 4\% PFA, and tissues were cryoprotected in 25\% PBSbuffered sucrose solution, embedded in O.C.T., and sectioned sagittally at 10 $\mu \mathrm{m}$ using an HM500M cryostat (Microm). Immunohistochemistry was performed after antigen retrieval as described previously (Lee et al., 2012). The following antibodies were used: anti-Tbr1 (1:100; Abcam, catalog \#ab31940 RRID:AB_2200219), anti-Tbr1 (1:250; Synaptic Systems, catalog \#328 005 RRID:AB_2620072, when used for dual IHC with Tbr2, Brn2, pKAP1, and $\gamma \mathrm{H} 2 \mathrm{AX})$, anti-Tbr2 (1;200; Abcam, catalog \#ab23345 RRID:
AB_778267), anti-Cuxl (1:100; Santa Cruz Biotechnology, catalog \#13024 RRID:AB_2261231), anti-Ctip2 (1:100, Abcam, catalog \#ab18465 RRID: AB_2064130), anti-Brn2 (1:200; GeneTex, catalog \#GTX114650 RRID: AB_10619683), anti-KAP1-phospho-Ser-824 (1:500; Bethyl Labs, catalog \#A300-767A), anti-active caspase-3 (1:500; BD Biosciences, catalog \#559565 RRID:AB_397274), anti-phospho-H2AX-Ser-139 (1:200; Cell Signaling Technology, catalog \#2577L RRID:AB_2118010), anti-phospho-H3-Ser-10 (1:500; Cell Signaling Technology, catalog \#9701L RRID:AB_331535), and anti-Tuj1 (1:500; Covance Research Products, catalog \#MMS-435P RRID: AB_2313773). Immunostaining of active caspase-3 and pKAP-1(S824) was visualized with a VIP substrate kit (Vector Laboratories, catalog \#SK-4600 RRID:AB_2336848) and biotinylated secondary antibody and avidin-biotin complex (Vectastain Elite kit; Vector Laboratories, catalog \#PK-6100 RRID: AB_2336819). Sections were counterstained with $0.1 \%$ methyl green (Vector Laboratories), dehydrated, and mounted with DPX (Fluka). For fluorescence, FITC- or Cy3-conjugated secondary antibody (Jackson Immunologicals) were used and counterstained with DAPI (Vector Laboratories, catalog \#H-1200 RRID:AB_2336790) or propidium iodide (Vector Laboratories, catalog \#H-1300 RRID:AB_2336791). TUNEL staining was done using the ApopTag system (Millipore Bioscience Research Reagents).

In situ cell counts. P5 and E15.5 brains were subjected to quantitative analysis to determine the indices of apoptosis and mitosis, respectively, during neurogenesis. Three brains per genotype were analyzed for each time point, and three representative sections per brain (nine sections per genotype) were used for quantification. Immunopositive cells for active 
Control

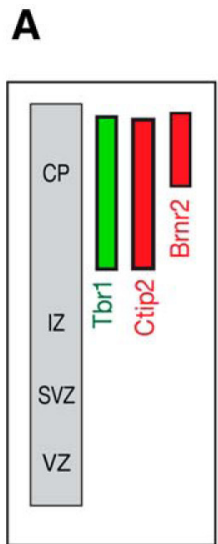

E15.5, neocortex

Prkdc $^{-/}$
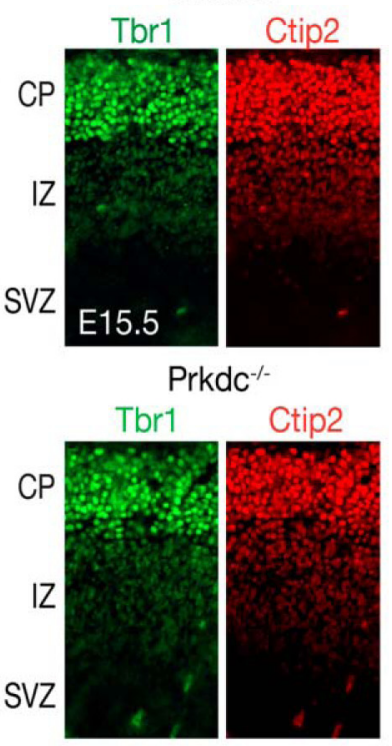

B
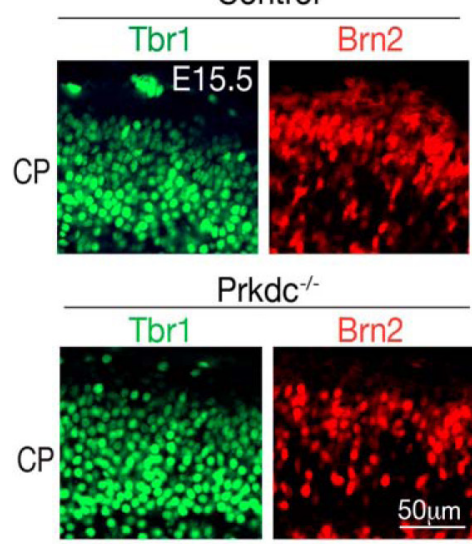

Prkdc- ${ }^{-1-}$

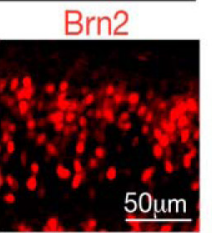

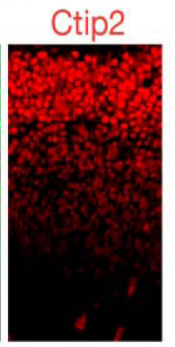

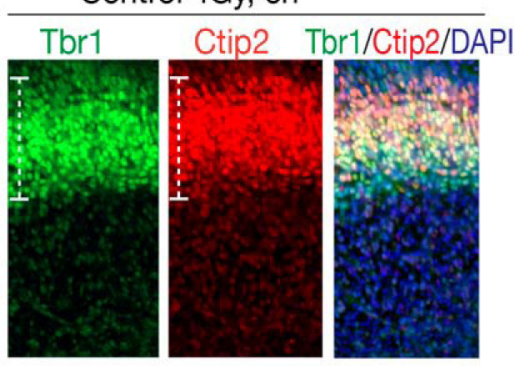

Prkdc $^{-1-} 4 \mathrm{~Gy}, 6 \mathrm{~h}$
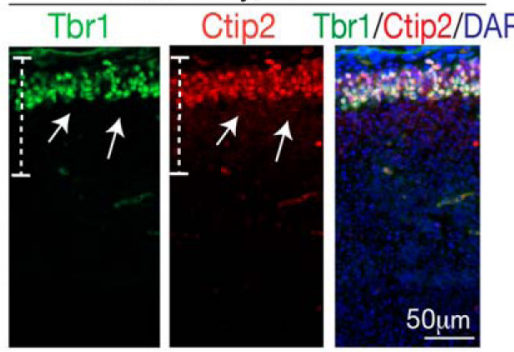

Control 4Gy, 6h
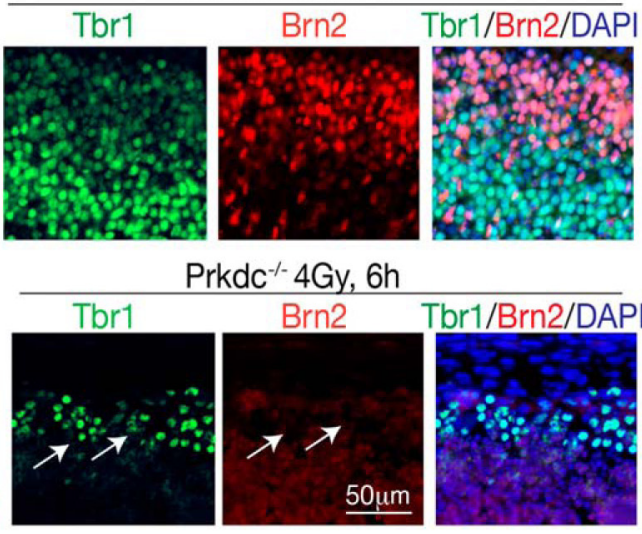
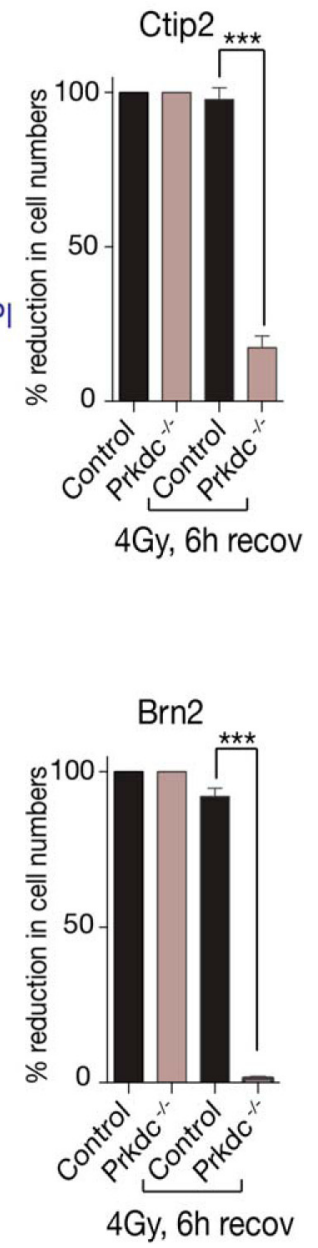

Figure 3. Differential sensitivity to DNA damage is observed within the developing CP. $A$, Sagittal sections of E15.5 neocortex show that within the Tbr ${ }^{+}$upper $C P$ layer are neuronal subpopulations at various stages of differentiation and maturity that can be identified using Ctip2 or Brn2. After IR, Tbr ${ }^{+} / \mathrm{Ctip}{ }^{+}$populations (white dashed lines) are markedly reduced in the Prdkc $^{-1-}$ neocortex (white arrows), whereas in the WT tissue these are unaffected. B, Tbr1 ${ }^{+} /$Brn2 ${ }^{+}$progenitors are almost entirely eliminated in Prdrkc ${ }^{-}-{ }^{-}$(white arrows), whereas in WT tissue the numbers of Brn2 ${ }^{+}$cells are reduced slightly compared with unirradiated controls (as quantitated in the adjacent graphs for Ctip2 and Brn2). ${ }^{* * *} p<0.0001$.

caspase- 3 were measured within $10 \times$ images of the $\mathrm{P} 5 \mathrm{CA} 1$ region. The neocortex was divided into four areas: ventricular zone (VZ), subventricular zone (SVZ), intermediate zone (IZ), and cortical plate (CP). $\mathrm{pH} 3($ ser10) cells in the apical region of the $\mathrm{VZ}$ were measured within $40 \times$ images of E15.5 embryonic cortices. Active caspase-3 in the E15.5 neocortex was quantified by counting in $110 \mu \mathrm{m}^{2}$ areas taken from $10 \times$ images and the percentages reported. For the P5 cerebellum, cells were measured within a $68 \mu \mathrm{m}^{2}$ area for active caspase-3. The developing P5 cerebellum was divided into two areas: white matter (WM) and the external granule layer (EGL). Postnatal day 11 brains were stained and quantified by percentage of cells that were positive for a particular marker. Graphs represent mean values of replicates, error bars the SEM, and $p<0.05$ was considered significant. When comparing two genotypes, $p$ values were calculated using unpaired Student's $t$ test (GraphPad, Prism version 7.0 RRID:SCR_002798). For comparisons involving multiple genotypes, a one-way ANOVA was conducted and, when significant, followed post hoc with Tukey's multiple comparisons (GraphPad, Prism version 7.0, RRID:SCR_002798).

Western blots. Protein extracts were prepared as described previously (Lee et al., 2012). After separation using NuPAGE $4 \%-12 \%$ Bis-Tris protein gels, proteins were identified using anti-DNA-PKcs Ab-4 mixture (1/100; Lab Vision, catalog \#MS-423-P1 RRID:AB_61152), anti-phospho-ATMser1981 (1:1000; R\&D Systems, catalog \#AF1655 RRID:AB_2062935), anti-
ATR (1:500; Santa Cruz Biotechnology, catalog \#sc-1887 RRID: AB_630893), anti-Chk2 (1:1000; Millipore, catalog \#05-649 RRID: AB_2244941), anti-p53-ser15 (1:1000; Cell Signaling Technology, catalog \#9284 RRID:AB_331464), anti-ATM (1:1000; Cell Signaling Technology, catalog \#2873S RRID:AB_2062659), anti-phospho-KAP1-ser824 (1:1000; Bethyl, catalog \#A300-767A RRID:AB_669740), and anti-KAP1 (1:2000; Abcam, catalog \#ab10484 RRID:AB_297223). HRP-conjugated secondary antibodies were used to visualize proteins using chemiluminescence. Equal protein transfer was confirmed using Ponçeau staining and/or anti-actin immunoblotting (1:500; Santa Cruz Biotechnology, catalog \#sc-1616 RRID: AB_630836) was used as a loading control.

\section{Results}

DNA-PKcs loss hypersensitizes to apoptosis in the neocortex and postnatal brain

Although many NHEJ core components are essential for neural development (Barnes et al., 1998; Gao et al., 1998b; Gu et al., 2000), DNA-PKcs is dispensable, with no overt neural phenotype reported in Prkdc $c^{-1-}$ mice (Gu et al., 2000). However, Scid mice (resulting from DNA-PKcs mutation) have been reported to show increased cell death in the developing nervous system, and cultured neurons from these mice showed increased sensitivity to 
A

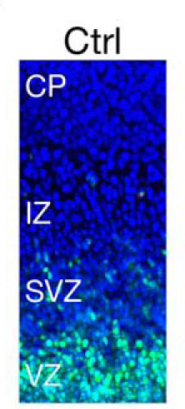

E15.5
4Gy, $1 \mathrm{~h}$

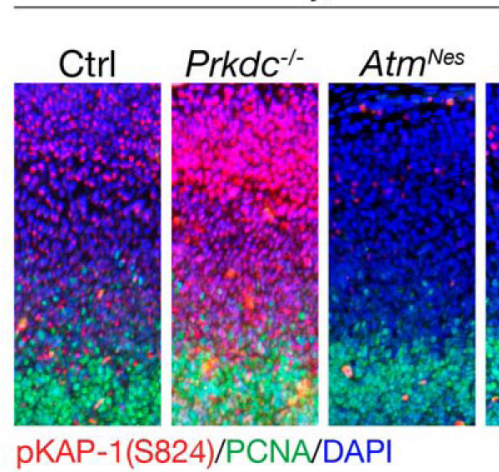

Atm Nes

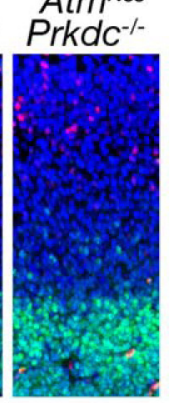

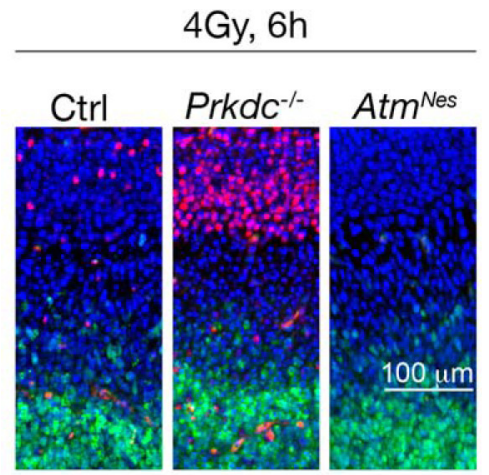

B

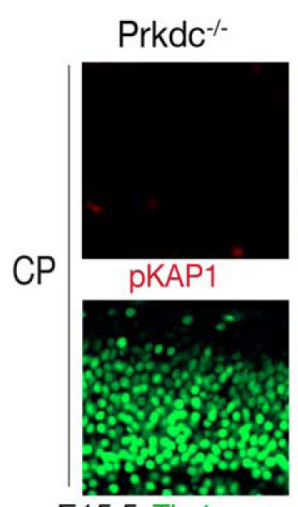

E15.5 Tbr1

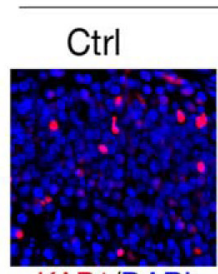

pKAP1/DAPI

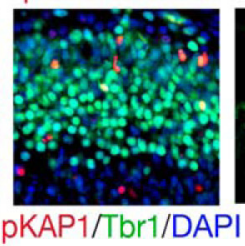

4Gy, $6 \mathrm{~h}$

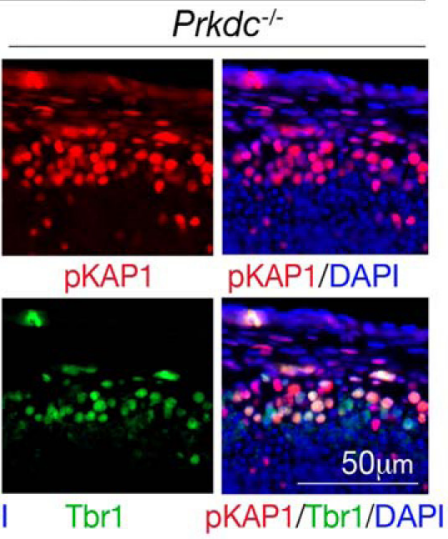

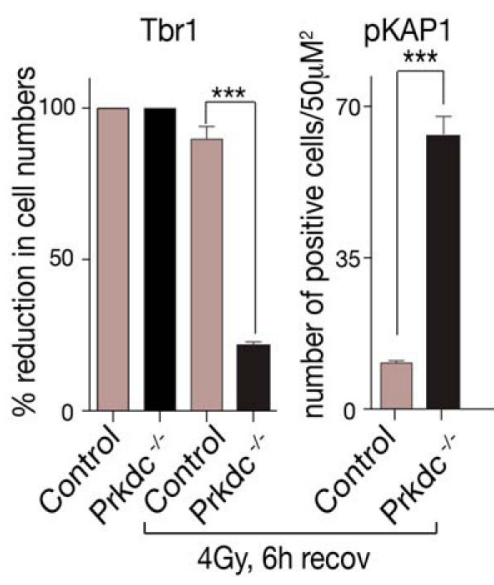

Figure 4. Differential sensitivity of the neocortex to IR reflects the activation of the DNA damage response involving phosphorylation of KAP1. $A$, Immunostaining for phosphorylation of KAP1(Ser824) at $1 \mathrm{~h}$ after IR in E15.5 sagittal sections. PKAP1 is markedly increased in Prkdc ${ }^{-1-}$ and persists at $6 \mathrm{~h}$ compared with controls; KAP1 phosphorylation is ATM-dependent and absent from Atm ${ }^{\text {Nes-cre }}$ tissue. PCNA immunostaining identifies proliferating progenitors. Sections were counterstained with DAPI (blue). B, In unirradiated E15.5 WT or Prkdc ${ }^{-\prime-}$ tissue, no pKAP1 is observed. After irradiation, phosphorylated KAP1 persists throughout the remaining Tbr ${ }^{+}$cells of the Prkdc ${ }^{-1-} \mathrm{CP}$, consistent with unrepaired DNA resulting in activation of the DNA damage response. Quantitation of the levels of Tbr1 and pKAP1 in WT and Prkdc ${ }^{-1-}$ cortex. $^{* * *} p<0.0001$.

staurosporine and kainic acid (Chechlacz et al., 2001; Vemuri et al., 2001; Liu et al., 2009). We therefore sought to determine how DNA-PKcs functions during the neural DDR, and additionally in the context of the related kinases ATM and ATR.

As neurogenesis is particularly susceptible to DNA damage (McKinnon, 2013), we used the neocortex to delineate DNAPKcs function, a tissue where the spatiotemporal effects of genotoxic stress can be readily assessed. In the developing murine cortex, the VZ contains neural progenitors and the SVZ contains a mixed population of intermediate progenitors and immature noncycling neural cells, whereas the IZ contains mostly nonproliferating cells undergoing migration and differentiation. More mature neurons and glial cells reside in the CP, before establishment of the final six-layered tissue (Molyneaux et al., 2007).

Following exposure of the E15.5 embryo to ionizing radiation (IR), DNA damage signaling is activated that ultimately results in apoptosis (Orii et al., 2006; Gatz et al., 2011; Barazzuol et al., 2015). We initially determined the regional impact of DNA-PKcs loss throughout the E15.5 neocortex using immunostaining of activated caspase- 3 as a surrogate marker for apoptosis. Compared with control tissue, which showed activation of caspase-3, the loss of DNA-PKcs substantially enhanced this response, and the greatest difference was seen in the nonreplicating differentiating IZ and CP (Fig. 1 $A, B$ ). Quantitation of active caspase-3 immunostaining showed a marked increase in apoptotic cells in the Prkdc $c^{-/-} \mathrm{CP}$, indicating that DNA-PKcs is important for suppressing cell death in differentiating neuronal regions (Fig. $1 B)$. Notably, and similar to the developing cortex, we also observed a dose-dependent hyperactivation of apoptosis in the postnatal P5 hippocampus (Fig. 1C). Both the Prkdc ${ }^{-/-}$cornu ammonis (CA1-3) and dentate gyrus (DG) showed a marked increase in activated caspase-3, indicating a hypersensitivity to DNA damage. Quantitation of the CA1 region (as an example) after increasing doses of IR showed a significant increase in sensitivity in the Prkdc $c^{-/-}$tissue (Fig. 1D). This suggests that the neuroprotective role DNA-PKcs after DNA damage features broadly in the nervous system.

To identify the cells hypersensitive to DNA damage in the

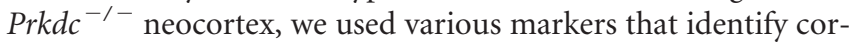
tical neuronal cell types. We used Tbr1, which is a transcription factor that regulates the laminar identity of postmitotic cortical neurons (Hevner et al., 2001; Bedogni et al., 2010), and Tbr2, a transcription factor required for generation of intermediate progenitor cells during corticogenesis, which is expressed in the SVZ (Englund et al., 2005; Sessa et al., 2008; Mihalas et al., 2016). Unirradiated WT and Prkdc ${ }^{-/-}$E15.5 tissue showed equivalent immunostaining patterns for Tbr1, indicating similar developmental profiles (Fig. 2A). However, after 4 Gy of IR, there was a 

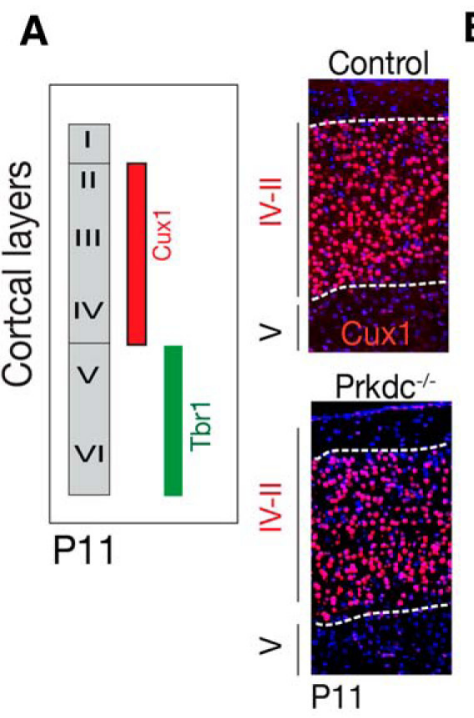

B

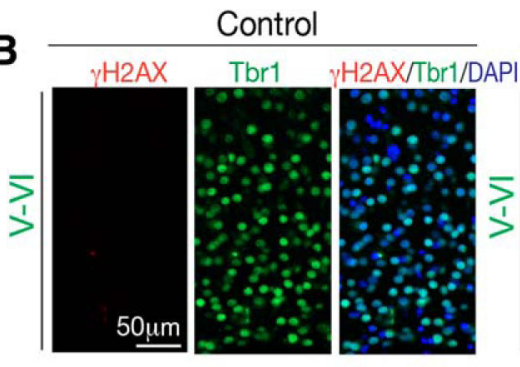

Prkdc $^{-1-}$

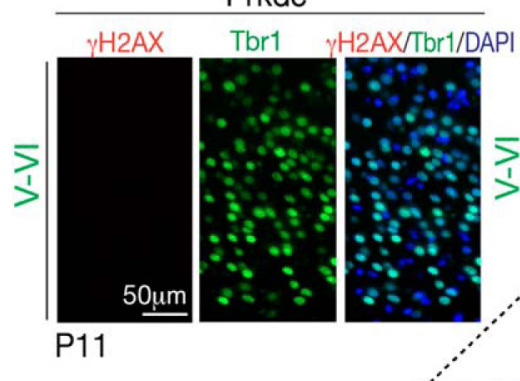

Control, 6Gy, 4h recov

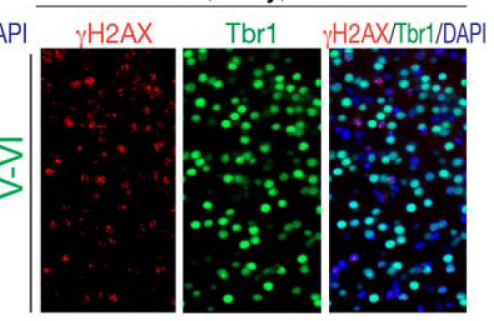

Prkdc $^{-/}, 6 \mathrm{~Gy}, 4 \mathrm{~h}$ recov

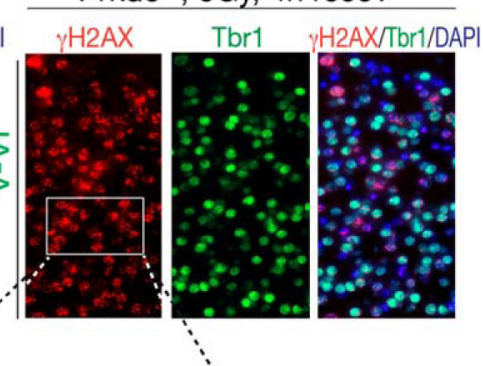

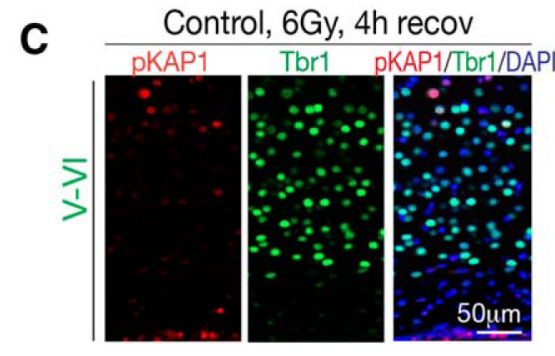

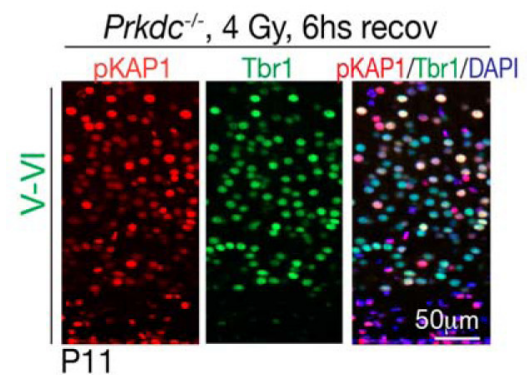

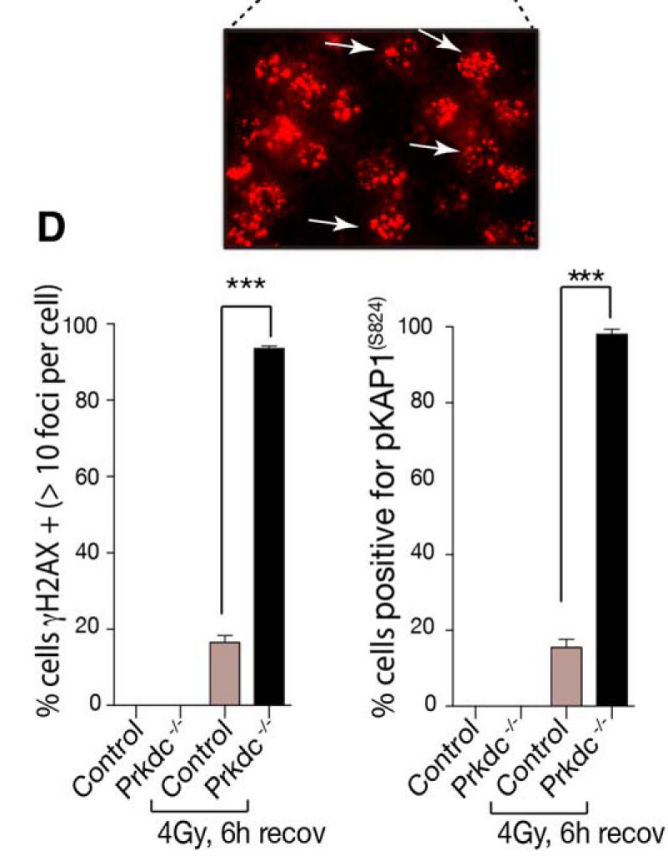

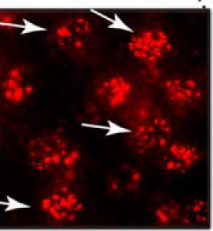

Figure 5. KAP1 and H2AX phosphorylation is enhanced in the Prkdc ${ }^{-/-}$P11 cortex. A, At P11, the six layer structure of the cortex is present (illustration), and both WT and Prkdc ${ }^{-/-}$are histologically similar, with Cux1 immunostaining of sagittal E15.5 sections used as an example. B, Phosphorylated H2AX(ser134), which identifies DNA DSBs, is largely absent from both WT and Prkdc ${ }^{-/-}$embryonic tissue, but after radiation $\gamma \mathrm{H} 2 \mathrm{AX}$ is abundant in the Prkdc ${ }^{-/-}$cortex compared with WT and associated with $\mathrm{Tbr}^{+}$neurons. The expanded view indicates the typical

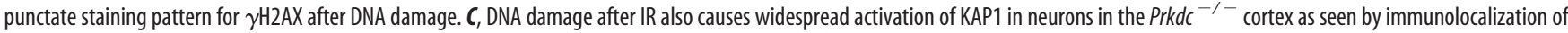
phosphorylated KAP1 and Tbr1. D, Quantitation of the levels of $\gamma \mathrm{H} 2 \mathrm{AX}$ and pKAP1 in WT and Prkdc ${ }^{-\prime-}$ cortex. $^{* * *} p<0.0001$.

substantial loss of $\sim 70 \%$ of the $\mathrm{Tbr}^{+}{ }^{+}$neurons in the Prkdc ${ }^{-\prime-}$ CP compared with only $\sim 10 \%$ in WT (Fig. $2 A$ ). For other cortical regions, we used Tbr2, which at E15.5 defines immature cells in the SVZ (Bulfone et al., 1999). Similar to the Tbr $1^{+} \mathrm{CP}$ cells, the Tbr2 ${ }^{+}$SVZ population in the Prkdc ${ }^{-\prime-}$ tissue was also substantially affected, with most (>95\%) of these cells being lost after IR in the Prkdc ${ }^{-1-}$ neocortex, compared with $\sim 15 \%$ in WT (Fig. $2 B)$. These data also indicate that the activated caspase- 3 cells shown in Figure $1 A$ subsequently undergo apoptosis.

To further determine the relative DNA damage susceptibility of neural populations, we used additional markers that define subpopulations within the $\mathrm{Tbrl}^{+}$neuronal cells of the developing neocortex. Ctip2 is a transcription factor localized to subcerebral projection neurons of the CP (Arlotta et al., 2005), whereas
Brn2 is involved in regulating upper layer cells of the $\mathrm{CP}$ (Dominguez et al., 2013; Oishi et al., 2016). Consistent with a heightened susceptibility of $\mathrm{Prkdc}^{-1-} \mathrm{Tbr} 1^{+}$progenitors to DNA damage (Fig. 2A), interrogation of these cells using Ctip2 revealed that a large fraction of $\mathrm{Tbr} 1^{+}$cells $(\sim 80 \%)$ in this neocortical region (i.e., Tbr $1^{+} \mathrm{Ctip} 2^{+}$cells) were hypersensitive and eliminated after IR (Fig. $3 A$ ). In stark contrast, the same Tbr $1^{+} \mathrm{Ctip} 2{ }^{+}$populations in the WT tissue were mostly resistant and showed only minor cell loss (Fig. 3A). Additionally, within this region, Brn2 ${ }^{+}$ cells were even more sensitive in the Prkdc ${ }^{-1-}$ tissue, as this population was completely lost after IR, compared with an $\sim 10 \%$ reduction observed in WT (Fig. 3B). Thus, DNA-PKcs protects the developing neocortex in the face of genome damage; and within this tissue, certain neurons (e.g., $\mathrm{Tbr}{ }^{+} \mathrm{Brn} 2^{+}$) are partic- 


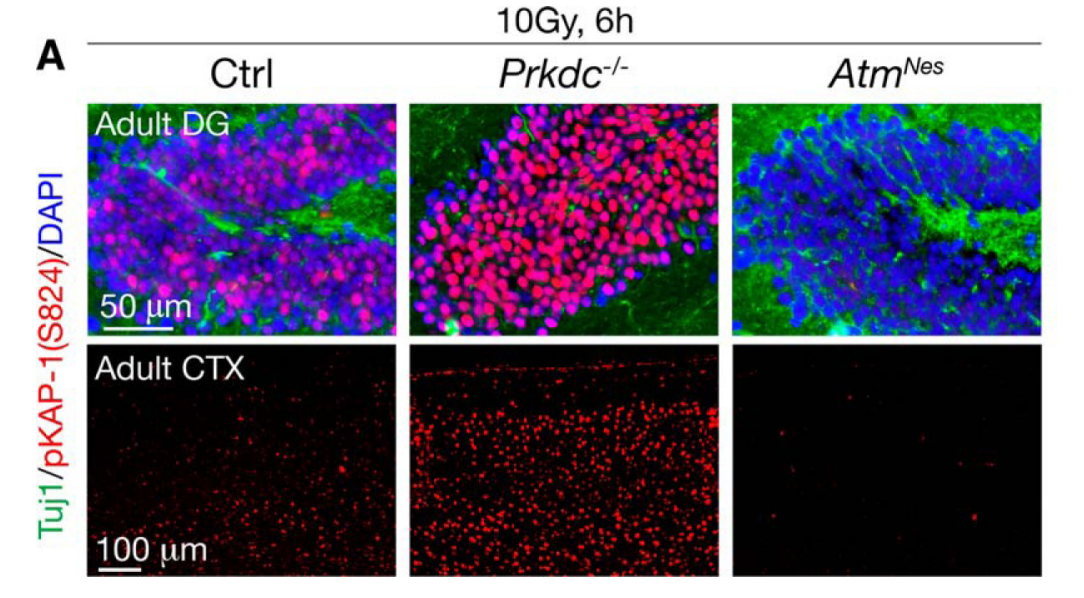

10Gy, 6h

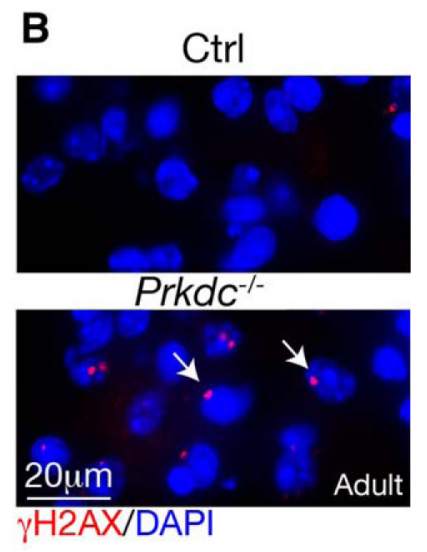

Figure 6. DNA-PKcs restrains DNA damage in adult neural tissue. $\boldsymbol{A}$, In irradiated adult dentate gyrus or cortex, DNA damage signaling is elevated in Prkdc ${ }^{-/-}$tissue. Consistent with

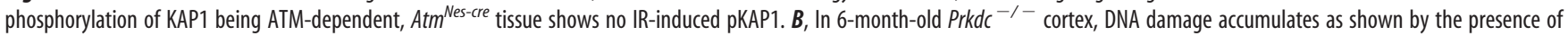
endogenous DNA strand breaks, as indicated using $\gamma \mathrm{H} 2 \mathrm{AX}$ immunostaining. The region of the cortex shown is an area directly superficial to the hippocampus.

ularly hypersensitive to DNA damage when DNA-PKcs is absent. This differential sensitivity is consistent with differentiation status of the neurons being a key determinant in susceptibility to IR (McKinnon, 2013), as the Brn $2^{+}$cells are a less differentiated cell type than the Ctip2 ${ }^{+}$cells at E15.5 (Molyneaux et al., 2007).

\section{The neuroprotective role of DNA-PKcs is enhancement of NHEJ}

IR hypersensitivity in the neocortex after DNA-PKcs loss could occur because of defective DNA repair (NHEJ) or attenuated DNA damage signaling due to absent kinase activity, both of which could result in increased DNA damage leading to apoptosis. Of the two possible DSB repair pathways, NHEJ is the pathway used by nonproliferating neural cells (Shull et al., 2009), as $H R$ requires cells in $S / G_{2}$ phase, where they contain sister chromatids as the repair template (Orii et al., 2006; Jasin and Rothstein, 2013). This implies that, if DNA-PKcs is primarily functioning as a DNA repair factor, its loss would likely impact DNA damage resolution of nonproliferative cortical cells.

To distinguish between these possible roles for DNA-PKcs, we examined DNA damage markers that identify activation of the DNA damage response. We initially assessed phosphorylation of the chromatin-associated protein KAP1 (KRAB-associated protein 1; TRIM28). Phosphorylation of KAP1 (pS824) occurs after DNA DSBs and is an ATM-dependent phosphorylation event, which is important for accessing DSBs in heterochromatin for repair (Ziv et al., 2006; Goodarzi et al., 2011). Compared with WT tissue, phosphorylated KAP1 in Prkdc ${ }^{-/-}$was abundant in the differentiating $\mathrm{CP} 1 \mathrm{~h}$ after radiation. By $6 \mathrm{~h}, \mathrm{pKAP} 1$ remained in the CP in the mutant, consistent with slower DNA DSB repair in the Prkdc $c^{-1-}$ noncycling differentiating cells (Fig. 4A). Notably, these DDR signaling events are ATM-dependent as they were absent from both Atm $^{\text {Nes-cre }}$ and Prkdc ${ }^{-/-} ;$Atm $^{\text {Nes-cre }}$ tissue. These data imply that DNA-PKcs loss compromises efficient DNA repair and increases DNA DSBs, which activates ATM causing KAP1 phosphorylation. To identify cell types with persistent pKAP1 in the CP, we used Tbr1 costaining (Fig. 4B). In the WT tissue, infrequent $\mathrm{pKAP} 1^{+}$cells were present throughout the intact $\mathrm{Tbr} 1^{+} \mathrm{CP}$ layer at $6 \mathrm{~h}$ after IR, implying DNA damage resolution. In contrast, widespread $\mathrm{Tbr}^{+}$cell loss after IR was evident in Prkdc $^{-1-}$ tissue (Fig. $4 B$ ). The remaining Tbr ${ }^{+}$ cells in the CP showed persistent pKAP1, implying that DSBs remained, likely due to a repair defect after DNA-PKcs loss. Thus, these data suggest that DNA-PKcs reduces the burden of DNA damage in $\mathrm{Tbrl}^{+}$neuronal cells via resolution of DSBs.

We next examined DNA damage signaling in the P11 cortex. We chose this developmental stage because these more mature neural populations do not engage apoptosis, and so assessment of DNA strand breaks via $\gamma \mathrm{H} 2 \mathrm{AX}$ in the absence of those formed during apoptosis is possible (McKinnon, 2013). Similar to the neocortex, we found no differences in histology between WT and Prkdc ${ }^{-/-}$at P11 using markers to distinguish all six cortical layers (Fig. 5A; as an example, Cux1 that delineates layers II-IV is shown). However, compared with the WT cortex, radiation of Prkdc ${ }^{-/-}$resulted in markedly elevated and persistent DNA DSBs in this tissue as indicated by $\gamma \mathrm{H} 2 \mathrm{AX}$ formation (Fig. $5 B$ ); the expanded inset image shows clear puncta of $\gamma \mathrm{H} 2 \mathrm{AX}$, typical of DNA strand breaks, rather than pan-nuclear staining typical of apoptosis (Shimada et al., 2015). $\gamma \mathrm{H} 2 \mathrm{AX}$ colocalizes with Tbr ${ }^{+}$ cells, indicating that DNA-PKcs functions in neurons to reduce DNA damage accumulation. Similarly, pKAP1 levels are also elevated in Prkdc $c^{-/-}$tissue, colocalizing with Tbr1 ${ }^{+}$cells (Fig. $5 C$ ). Comparative quantitation of $\gamma \mathrm{H} 2 \mathrm{AX}$ and pKAP1 present in irradiated P11 WT and Prkdc $c^{-1-}$ tissue is shown in Figure 5D.

Finally, to compare DNA-PKcs function in adult brain to earlier developmental stages, we examined radiation-induced DNA damage signaling in the adult cortex and DG. As shown in Figure $6 A$, compared with WT, elevated DNA damage signaling determined using pKAP1 immunohistochemistry was found in $P r k d c^{-/-}$DG and cortex after IR treatment. Additionally, we also found widespread endogenous DNA breaks as shown by $\gamma \mathrm{H} 2 \mathrm{AX}$ in Prkd $c^{-/-}$cortex compared with WT (Fig. 6B), indicating that DNA-PKcs protects the adult brain from endogenous DNA damage accumulation.

\section{Hypersensitivity and enhanced DNA damage signaling occur} in Prkdc $c^{-/-}$cerebellar progenitors

We expanded our analysis from cortical structures to include the cerebellum to further corroborate the impact of DNA-PKcs loss toward neural genome integrity. The cerebellum continues development after birth (for $\sim 3$ weeks in the mouse) as the EGL generates granule neurons that migrate inwards to form the inner granule neuron layer as the cerebellum matures (Butts et al., 2014).

After IR treatment, increased activated caspase-3 levels were observed in the Prkdc ${ }^{-/-}$P5 cerebellum compared with controls, with significantly more death in both the EGL and WM of the 
A
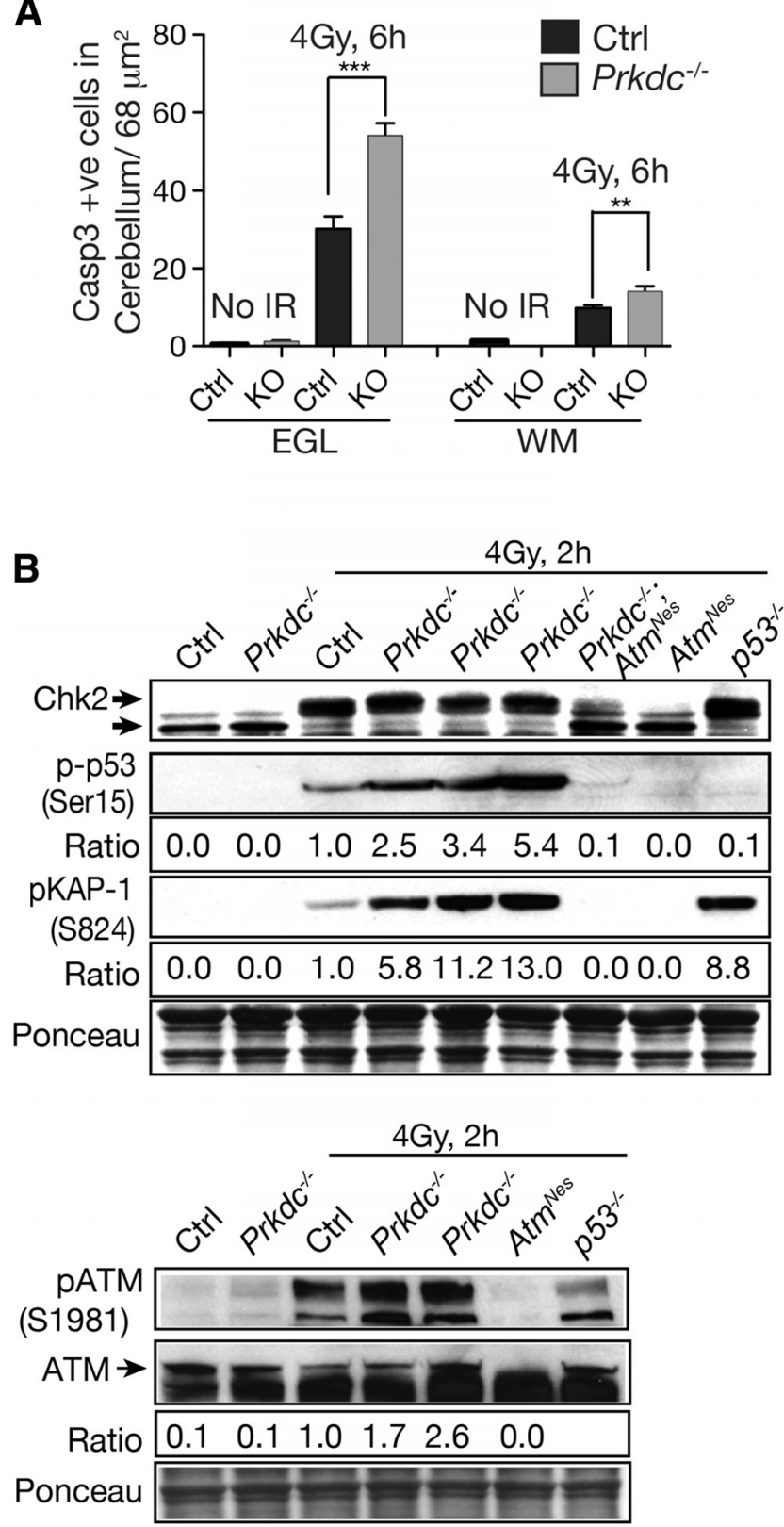

P5 Cerebellum

Figure 7. DNA-PKcs protects the cerebellum from excessive DNA damage. $A$, Quantification of active caspase- 3 in the irradiated $P 5$ cerebellum shows increased apoptosis in both the Prkdc ${ }^{-1-}$ EGL and WM. Graphs represent mean values of replicates ( $n=3$ animals per group). Error bars indicate SEM. ${ }^{* *} p<0.01 .{ }^{* *} p<0.001$. B, Phosphorylation of p53(ser15), KAP(ser824), and ATM(1981) was increased in irradiated P5 Prkdc ${ }^{-1-}$ cerebellar tissues compared with controls; CHK2 activation is shown as a band-shift (top arrow). These events are ATM-dependent and absent in $\mathrm{Atm}^{\text {Nes-cre }}$ tissue. Ponçeau staining shows equal protein transfer. Ratios indicate levels of radiation-induced phosphorylation of the respective DNA damage signaling components.

mutant tissue (Fig. 7A). Thus, loss of DNA-PKcs in the cerebellum also hypersensitizes to apoptosis after DNA damage, further indicating that DNA-PKcs broadly restrains the detrimental effect of DNA damage throughout the nervous system.

We then used Western blot analyses of WT and Prkdc ${ }^{-1-}$ cerebellar tissue to identify key protein modifications characteristics of the DDR, to assess the impact of DNA-PKcs loss toward DNA damage signaling. We used whole P5 cerebella at $2 \mathrm{~h}$ after IR (a time before apoptotic morphology is found in the immature EGL), enabling unambiguous identification of DNA damageinduced signaling events. We found radiation-activated CHK2, as indicated by retarded gel mobility, and enhanced phosphorylation of p53 (pSer15) and KAP1 (pSer824) in Prkdc ${ }^{-1-}$ tissue compared with controls (Fig. 7B). ATM phosphorylation was also increased in $P r k d c^{-/-}$tissue after IR, consistent with elevated levels of unrepaired DNA breaks (Fig. $7 B$ ). Tissues from $\mathrm{Atm}^{\text {Nes-cre }}$ and Prkdc ${ }^{-1-} ; \mathrm{Atm}^{\text {Nes-cre }}$ serve as controls for Chk2, p53, and KAP1 phosphorylation after IR as these are ATMdependent events. These data suggest that increased DNA damage in the Prkdc ${ }^{-1-}$ tissue after IR leads to enhanced ATMdependent DNA damage signaling, which ultimately results in elevated apoptosis. The increased phosphorylation levels of p53 and KAP1 further indicate that loss of DNA-PKcs exacerbates DNA damage signaling because of unrepaired DNA.

\section{DNA-PKcs, ATM, and ATR integrate DNA damage signaling} during neurogenesis

The physiological interrelationship between the DNA damageresponsive PI3K kinases remains unclear. In the immune system, ATM and DNA-PKcs coordinate DSB repair and apoptosis during class switch recombination (Callén et al., 2009; Lee et al., 2013), and ATM and DNA-PKcs can both phosphorylate H2AX after DNA damage (Stiff et al., 2004). To understand how DNAPKcs function is integrated in the DDR during neural development, we generated mice with a combinatorial loss of DNA-PKcs with ATM and ATR. We generated Prkdc ${ }^{-1-} ; \mathrm{Atm}^{\text {Nes-cre }}$ and $\operatorname{Prkdc}^{-1-} ;$ Atr ${ }^{\text {Nes-cre }}$ double knock-outs (DKO) and Prkdc ${ }^{-1-}$; $(\text { Atm;Atr })^{\text {Nes-cre }}$ triple knock-out animals (TKO). Despite synthetic lethality after germline inactivation of ATM and DNA-

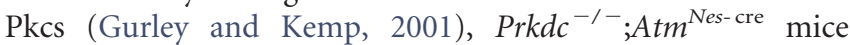
showed no overt phenotype. Prkdc ${ }^{-\prime-} ;(\text { Atm; Atr })^{\text {Nes-cre }}$ were also born alive, although they only survived for a day, an accelerated phenotype compared with $A t r^{\text {Nes-cre }}$ single-mutant mice (Lee et al., 2012).

Because of the reports linking overlapping functions of these kinases (Matsuoka et al., 2007) and our observation that doubleor triple-mutant embryos showed no obvious defects at E15.5, we used Western blots to confirm loss of the respective proteins. Western blot analysis of WT tissue compared with that from DKO (Prkdc ${ }^{-1-} ;$ Atm $\left.^{\text {Nes-cre }}\right)$ and TKO confirms these proteins were absent from E15.5 embryos (Fig. 8A). Moreover, analysis of DNA damage signaling by examining p 53 and KAP1 phosphorylation also confirmed this process was defective after ATM loss (Fig. 8A). We then determined apoptosis after exposure to IR by active caspase-3 immunostaining. We found that, whereas active caspase-3 levels were increased in $\operatorname{Prkdc}^{-/-}$, apoptosis was greatly reduced in $\mathrm{Atm}^{\mathrm{Nes}-\mathrm{cre}}$ tissues (Fig. $8 B, C$ ). In contrast, ATR loss led to a sparing of replicating cells in the VZ but had little effect on DNA damage-induced apoptosis in noncycling cells in the SVZ and CP (Fig. $8 B, C$ ), which is consistent with its requirement for sensing replication stress (Nam and Cortez, 2011).

The combined loss of Atm and Atr eliminated IR-induced apoptotic signaling as demonstrated by a lack of active caspase- 3 immunostaining throughout all regions of the neocortex (Fig. 8B). In comparison, $\mathrm{Prkdc}^{-1-} ; \mathrm{Atm}^{\text {Nes-cre }}$ embryos showed reduced active caspase-3 signal compared with $P r k d c^{-1-}$ (Fig. 8D) consistent with ATM being a key regulator of apoptosis after DNA damage (Herzog et al., 1998). In contrast, dual inactivation of DNA-PKcs and ATR resulted in radiation-induced apoptosis similar to DNA-PKcs (Fig. $8 B, D$ ), reflecting the primary role of ATR in VZ progenitors (Nam and Cortez, 2011; Lee et al., 2012; 


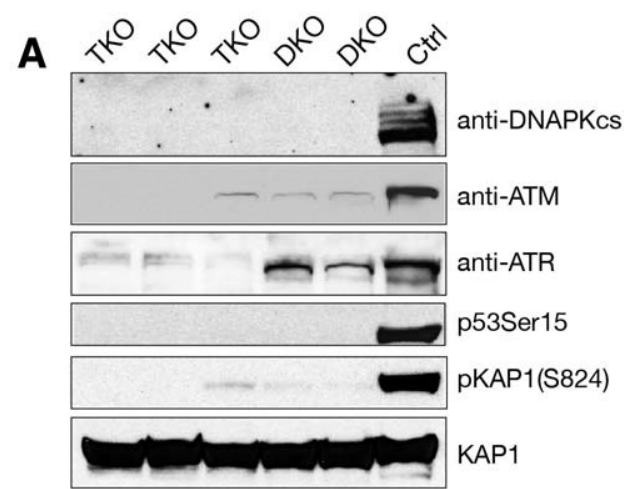

$$
\text { 4Gy, } 2 h
$$

\section{B}

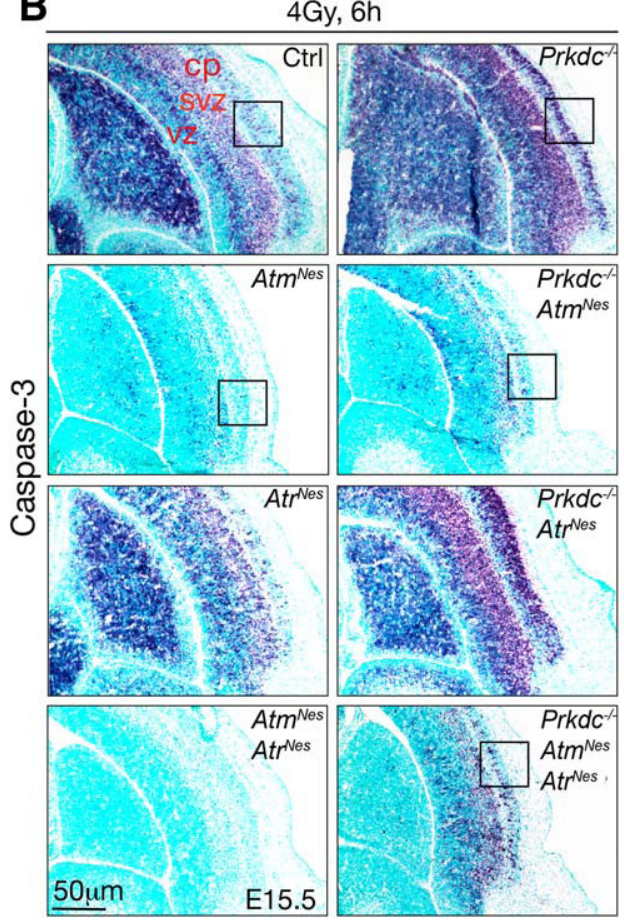

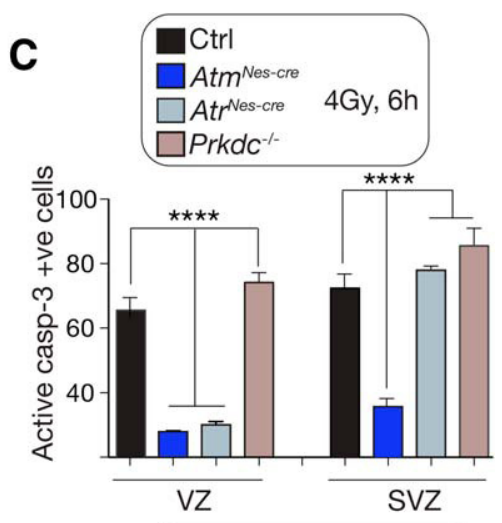

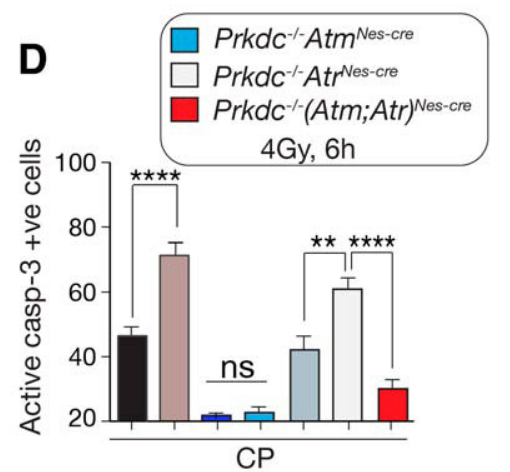

E

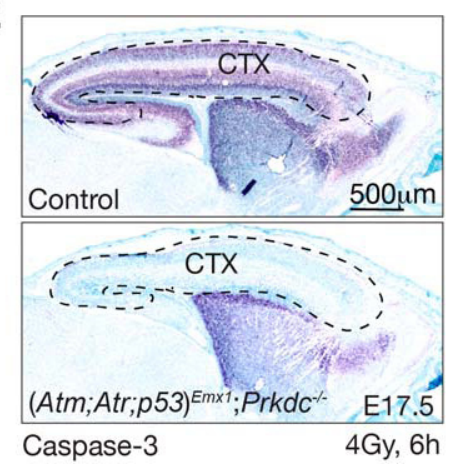

Figure 8. Integration of DNA damage signaling by DNA-PKcs and ATM and ATR. A, Western blot analysis confirms protein deletion of DNA-PKcs, ATM, and ATR in the various compound genotypes. Minor residual ATM or ATR may be contaminating wild-type cells or incomplete gene deletion. However, defective phosphorylation of p53 and KAP1 in the P5 cerebellum after radiation confirms compromised DDR signaling in mutant tissue. B, Sagittal section of E15.5 embryos shows that radiation induced apoptosis in the neocortex using activated caspase-3 immunostaining. ATM deletion ( Atm $^{\text {Nes-Cre }}$ ) substantially reduces apoptotic signaling throughout the cortex. The combined loss of ATM and ATR eliminates IR-induced apoptotic signaling, whereas DNA-PKcs loss sensitizes immature, noncycling cortical neurons to IR-induced apoptosis, even in the absence of ATM and ATR. Boxes represent CP. C, Quantitation of activated caspase-3 levels in different cortical regions shows the relative contribution of the various kinases to IR-induced apoptosis in specified cortical areas. ${ }^{* * *} p<0.0001$. D. Coincident loss of DNA-PKcs with Atm ${ }^{\text {Nes-cre }}$ or $(\text { Atr; Atm })^{\text {Nes-cre }}$ still sensitizes the CP to DNA damage. ${ }^{* * *} p<0.0001 .{ }^{* *} p<0.01$. Dual inactivation of ATM and ATR resulted in an absence of active caspase-3-positive cells in the VZ. Genotype legends shown are in addition to those already presented in $C$ E, Active caspase-3 immunostaining of irradiated E17.5 (Atm;Atr;p53) ${ }^{\text {Emx1-cre }}$;Prkdc ${ }^{-1-}$ brain compared with WT control shows that apoptosis in the TKO is p53-dependent.

Zhou et al., 2012). ATM can also activate DNA damage-induced apoptosis in the VZ (Shull et al., 2009; Gatz et al., 2011). However, after radiation apoptosis still occurred in the TKO embryo, albeit this was mostly restricted to the differentiated cells (Fig. $8 B, D$ ). The specific activation event (possibly still a protein kinase) leading to IR-induced apoptosis in the absence of all three DNA damage-response kinases is unknown. Moreover, similar to IR-induced apoptosis during neurogenesis being p53-dependent (Lee et al., 2001; Orii et al., 2006), this was also the case in the TKO (Fig. 8E). Collectively, these data illustrate distinct spatiotemporal functions for each kinase as DNA-PKcs prevents damage accumu- lation in postmitotic cells, where ATM is the kinase that transduces DNA damage signaling. In contrast, in proliferative progenitors, ATR monitors replication stress and modulates DNA damage-induced apoptosis.

\section{ATR uniquely controls the IR-induced $\mathrm{G}_{2}$ checkpoint}

The data above indicate distinct roles for DNA-PKcs, ATM, and ATR in signaling DNA damage during neural development. The response to DNA damage also involves cell cycle checkpoint activation, and ATM and ATR in particular have been directly linked to this process. Whereas ATM modulates the DNA damage-induced $G_{1}$ and $S$ phase checkpoint, ATR is considered important for establishing the $G_{2}$ and $S$ phase checkpoints in vitro (Bartek et al., 2004; Shiloh and Ziv, 2013). To establish whether these kinases have unique roles in modulating cell cycle checkpoints in vivo in the setting of the nervous system, we analyzed IRinduced cell cycle dynamics in cortical progenitors after DNA damage. Proliferating neural cells in the VZ undergo dynamic nuclear positioning reflective of cell cycle phases, where mitotic cells reside at the apical surface of the VZ and cells in $S$ phase at the basal surface (Spear and Erickson, 2012). Progenitors in M phase can be identified using antibodies for histone $\mathrm{H} 3$ phospho-ser10 ( $\mathrm{pH} 3$ ), which normally distribute along the apical surface of the VZ (Fig. 9A). Therefore, we compared the various kinase mutants after radiation and used $\mathrm{pH} 3$ to identify $\mathrm{M}$ phase cells. We found much reduced $\mathrm{pH} 3$ immunostaining in $P r k d c^{-\prime-}$ and $\mathrm{Atm}^{\text {Nes-cre }}$ tissue after radiation, whereas abundant $\mathrm{pH} 3-$ immunopositive $\mathrm{M}$ phase cells were present in Atr $^{\text {Nes-cre }}$ tissue (Fig. 9B). Importantly, in unirradiated tissue, no differences were found in the distribution of $\mathrm{pH} 3$ between genotypes (Fig. 9C). This implies that ATR activates cell cycle arrest to prevent irradiated cells continuing through the cell cycle, likely to facilitate DNA repair. This may account for sparing of the VZ cells in Atr ${ }^{\text {Nes-cre }}$ as arrested cells will resist apoptosis.

To determine the influence of the other kinases, we analyzed compound mutants, including $\operatorname{Prkdc}^{-/-} ; \mathrm{Atm}^{\text {Nes-cre }}, \mathrm{Prkdc}^{-1-}$; Atr ${ }^{\text {Nes-cre }},(A t m ; A t r)^{\text {Nes-cre }}$ and Prkdc ${ }^{-1-} ;(\text { Atm; } A \text { Atr })^{\text {Nes-cre }}$ to determine how DNA-PKcs and ATM influenced checkpoint regulation. In each case, when ATR was inactivated, we found similar levels of $\mathrm{pH} 3$ accumulation at the apical boundary, indicating that the other kinases did not influence the kinetics of accumulation. In $\mathrm{Prkdc}^{-/-} ; \mathrm{Atr}{ }^{\text {Nes-cre }}$, we observed less $\mathrm{pH} 3 \mathrm{accu}-$ mulation, which may reflect increased DNA damage in $\mathrm{G}_{1}$ associated with DNA-PKcs loss leading to apoptosis (Fig. 9C). Thus, ATR alone controls the $\mathrm{G}_{2} / \mathrm{M}$ checkpoint after IR and contribu- 

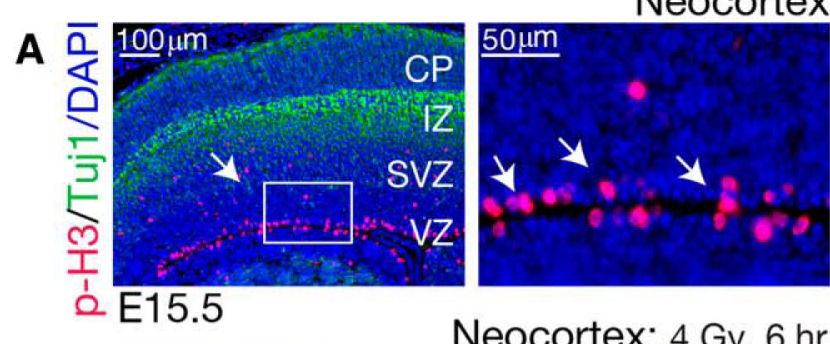

B
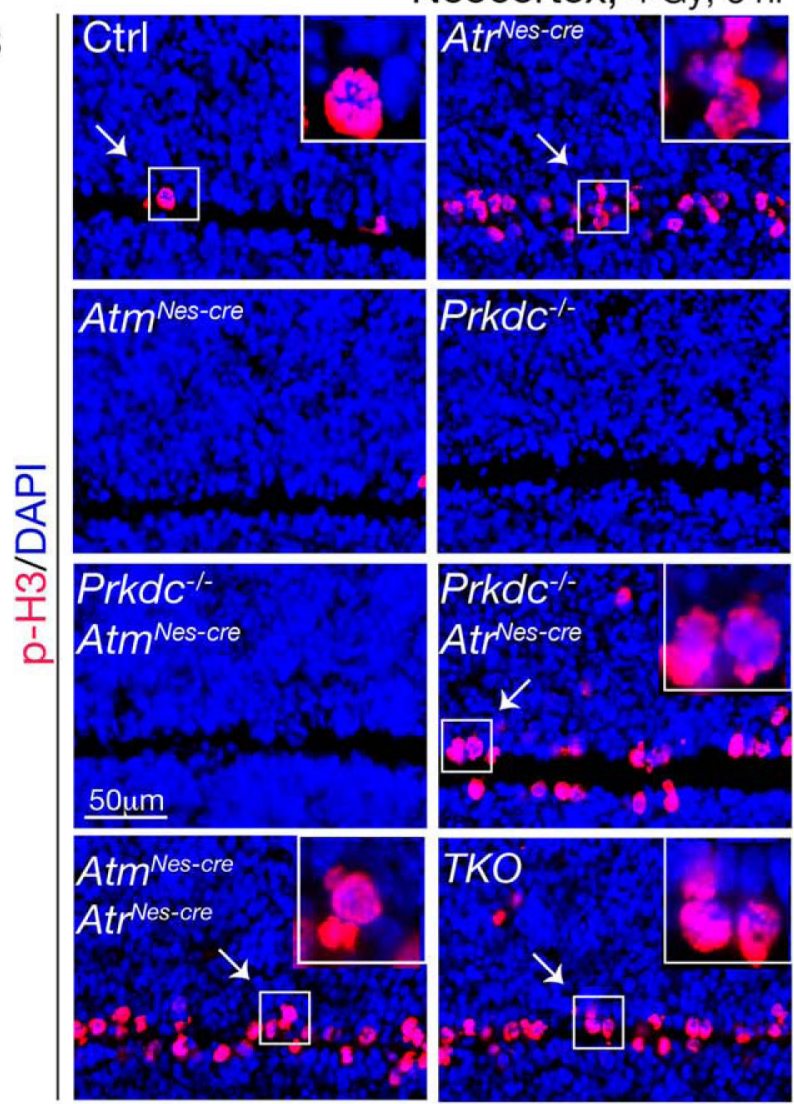

E15.5

C

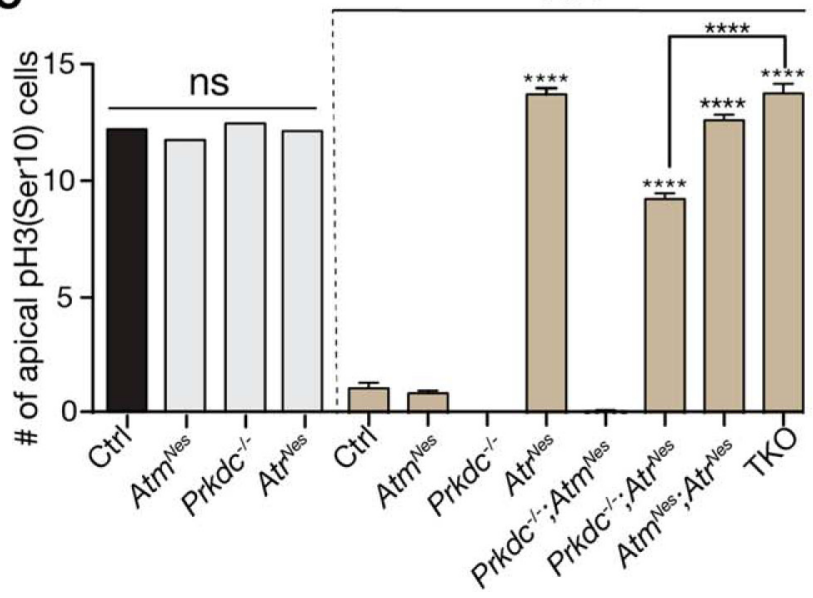

Figure 9. ATR controls the DNA damage-induced $G_{2}$ checkpoint. $\boldsymbol{A}$, Apical mitotic cortical progenitors in $\mathrm{G}_{2} / \mathrm{M}$ in unirradiated WT sagittal E15.5 cortex sections were identified using histone $\mathrm{pH} 3$ (Ser10) (p-H3; red). Adjacent image, Expanded view of the boxed region. A neuronal differentiation marker (Tuj1; green) is included as a comparison. $\boldsymbol{B}$, Irradiated WT and various mutant neocortices show $\mathrm{pH} 3$ accumulation after DNA damage in Atr $^{\text {Nes-cre }}$ tissue, indicating that ATR controls the $\mathrm{G}_{2} / \mathrm{M}$ checkpoint. Coincident loss of ATR or ATM with PRKDC still

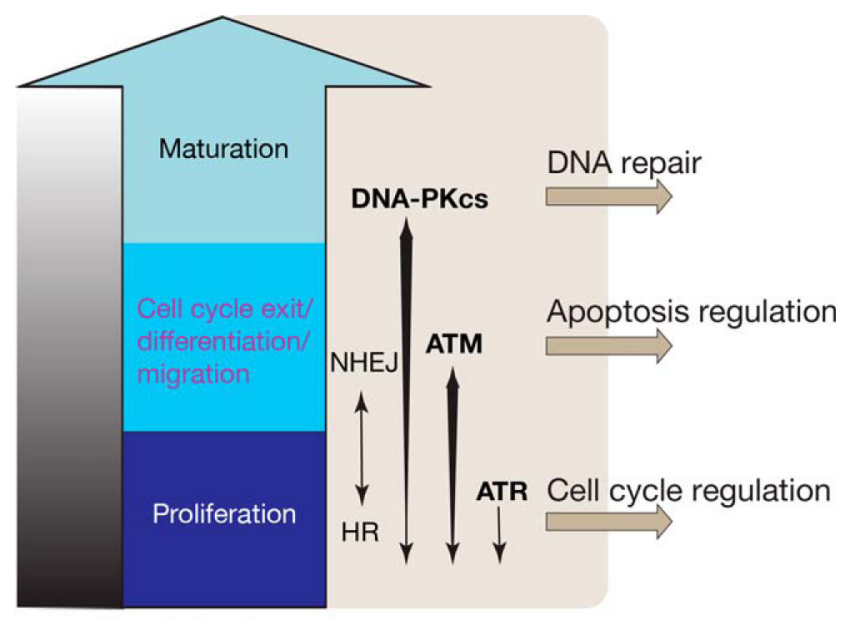

Neural development

Figure 10. DNA-PKcs, ATM, and ATR provide genome maintenance at different stages of neural development. Genome stability is maintained during neural development by independent functions of key DNA damage-response kinases that integrate the maintenance of genome stability. DNA-PKcs, ATM, and ATR can function independently at different stages of neural development to regulate cell cycle control, apoptosis, and DNA repair after genome damage. The available pathways for DNA DSB repair change as cells differentiate, with NHEJ becoming the main pathway for repair of this lesion in nonproliferating cells (i.e., those that are differentiated and mature). HR is operative in cycling cells as it requires a sister chromatid present in the $\mathrm{S}$ and $\mathrm{G}_{2} / \mathrm{M}$ phase of the cell cycle as a repair template. Although this schema outlines independent protein kinase functions relevant to the current study, multiple additional roles for theses kinases (not indicated), especially for ATM, have been established. Notwithstanding this, it is apparent that each kinase has separate independent roles linked to the proliferative and differentiation status of the nervous system.

tions of the other kinases to either the $G_{1}$ or $S$ phase checkpoint is negligible, at least in the neocortex.

\section{Discussion}

Here we have used mouse genetics to explore DNA damage signaling within a physiologic context, and identified multiple levels of neuroprotection provided by key DNA damage-responsive kinases: DNA-PKcs, ATM, and ATR. DNA-PKcs prevents DNA damage accumulation, particularly in noncycling cells, ranging from immature progenitors to mature neuronal populations. ATR modulates the cell cycle $\mathrm{G}_{2} / \mathrm{M}$ checkpoint in proliferating neuroprogenitors, whereas ATM is required for DNA damageinduced apoptosis in immature progenitors. In this manner, each DDR kinase has unique and nonoverlapping essential roles that collectively provide expansive protection against genome instability in the nervous system, thereby forming a broad barrier to neural genome instability (Fig. 10).

Analysis of the response of DNA-PKcs-null cortical progenitors to radiation-induced DNA damage revealed a marked sensitivity of nonproliferative progenitors that were undergoing differentiation and migration. In the $P r k d c^{-1-}$ neocortex at E15.5, abundant radiation-induced apoptosis was readily apparent in the IZ and CP. Within the CP, more immature cells (e.g., Tbr $1^{+} \mathrm{Brn} 2^{+}$) showed greater hypersensitivity to IR compared with the $\mathrm{Tbr} 1{ }^{+} \mathrm{Ctip} 2{ }^{+}$population. Albeit limited, DNA-PKcs

$\leftarrow$

results in accumulation of $\mathrm{pH} 3$ after DNA damage. Inset, Expanded from white boxed regions Sections are from embryos recovered $6 \mathrm{~h}$ after $4 \mathrm{~Gy}$ of radiation. $\mathrm{C}$, Quantitation of $\mathrm{pH} 3$-positive cells after radiation in the various genotypes shows that ATR regulates the neocortical $G_{2} / M$ checkpoint. Graphs represent mean values of replicates ( $n=3$ animals/group). Error bars indicate SEM. ${ }^{* * * *} p<0.0001$. 
also protected proliferative progenitors in the $\mathrm{VZ}$ after radiation, possibly reflecting the need for repair of DNA damage in $G_{1}$. The less obvious impact of DNA-PKcs loss in the VZ may relate to the sensitivity of these progenitors to radiation doses we used, as these cells can undergo apoptosis after DNA DSBs introduced by as little as 0.13 Gy of radiation (Hoshino and Kameyama, 1988; Hoshino et al., 1991). Therefore, the consequence of DNA-PKcs loss in this population may be negligible with radiation doses in the range used in our study.

In contrast to other key NHEJ factors, loss of DNA-PKcs had distinctly less physiological impact, especially in the nervous system (Barnes et al., 1998; Gao et al., 1998a; Frank et al., 2000; Gu et al., 2000; Lee et al., 2000). This is somewhat surprising as we found that DNA-PKcs was clearly required to restrain radiationinduced DNA damage accumulation and apoptosis in this tissue. This may reflect the relative dispensability of certain NHEJ components for low-level repair of endogenous DNA lesions ( $\mathrm{Gu}$ et al., 2000), with XRCC4/LIG4 in conjunction with accessory factors, such as XLF being sufficient for repairing low levels of damage. Importantly, in regions where higher endogenous damage would be expected to occur, such as the rapidly proliferative neural stem and progenitors in the VZ, HR will be intact in Prkdc ${ }^{-/-}$ tissue and able to address replication-associated DNA breaks. Studies involving hypomorphic mutants of Lig4 (Lig4 ${ }^{\mathrm{Y} 28 \mathrm{C}}$ ) have shown that incapacitation of LIG4 impacts the VZ/IZ after lowlevel radiation exposure (Gatz et al., 2011). Our analysis with $P r k d c^{-1-}$ shows that there is an increase in apoptosis in the VZ of $\operatorname{Prkdc^{-1-}}$ tissue, but a more marked sensitivity in the SVZ and noncycling noncycling IZ/CP is readily apparent, consistent with NHEJ being the main DSB repair pathway in noncycling neural cells.

ATR loss resulted in reduced apoptosis in the proliferative cells of the VZ. ATM is a critical signaling intermediate for transducing the DNA damage signal via p53 to activate apoptosis, particularly in the immature but postmitotic cells in the developing nervous system, and its inactivation can lead to a block in apoptosis (McKinnon, 2012). Notably, dual inactivation of ATM and ATR eliminates IR-induced apoptosis in the neocortical VZ, implying that a portion of $\mathrm{VZ}$ progenitors may be exiting the cell cycle before commencement of migration. The reduced apoptosis after ATR loss might be seen as counterintuitive to the fact that damaged cells accumulate in M phase in Atr ${ }^{\text {Nes-cre }}$ neocortex. Possibly, in this situation, cells accumulated in $\mathrm{M}$ phase are not competent for apoptosis and are eliminated via other means, such as autophagy.

Congenital human neurologic syndromes resulting from mutations in DNA-PKcs, ATM, or ATR underscore their importance in the nervous system (O'Driscoll et al., 2004; van der Burg et al., 2009; McKinnon, 2012; Woodbine et al., 2013). As the development of the nervous system involves the programmed elimination of cells (Buss et al., 2006; Yamaguchi and Miura, 2015), then genome-damaged progenitors would normally be easily replaced by the overabundance of progenitors produced during development. However, given the neurodevelopmental abnormalities associated with certain genome instability syndromes (e.g., ATR mutations), there is nonetheless clearly an ongoing need for genome surveillance. Our data provide the first coordinated analysis of these three principal DNA damageresponsive kinases, in a disease-relevant setting. Further, our study contrasts other settings where more direct cooperativity between these factors is observed, such as early embryonic lethality observed after ATR loss or dual germline inactivation of ATM and DNA-PKcs (Brown and Baltimore, 2000; de Klein et al.,
2000; Gurley and Kemp, 2001). Our findings suggest that DNAPKcs is important for the prevention of DNA damage in immature noncycling progenitors and the increased genomic damage in this population would result in apoptosis and cell loss contributing to the microcephalic phenotypes present in humans with PRKDC mutation (van der Burg et al., 2009; Woodbine et al., 2013). In the case of ataxia telangiectasia resulting from ATM deficiency, immature progenitors that incur DNA damage would normally undergo apoptosis, but the loss of ATM would result in cell sparing and the inappropriate incorporation of the damaged cell into the nervous system. The compromised $\mathrm{G}_{2}$ checkpoint resulting from ATR deficiency and DNA damage would also likely result in a phenotype reflective of that seen in Seckel syndrome individuals with hypomorphic ATR mutation, where systemic developmental defects are linked to aberrations of proliferation (O'Driscoll et al., 2003; Murga et al., 2009).

Of the three mouse models, only ATR loss effectively reflects the phenotypic severity seen in humans. Although individuals with (germline) inactivating mutations in ATM and DNA-PKcs have profound neurologic issues, murine models of this deficiency fail to show overt neuropathology, possibly reflecting a general higher threshold for genome damage to manifest in the mouse. However, in the case of ATM (Herzog et al., 1998; Shull et al., 2009; Katyal et al., 2014) and shown here for DNA-PKcs loss, there are nonetheless very clear consequences in the mouse nervous system after loss of these factors in the face of DNA damage. Restricting analysis to neural tissues provides a more disease-relevant context for determining functional contributions of these kinases during tissue homeostasis. The fact that neural development proceeds in the absence of all three DNA damage-responsive kinases may reflect a primary role for these factors in preventing stochastic adverse events that impact tissue homeostasis.

\section{References}

Aguilera A, García-Muse T (2012) R loops: from transcription byproducts to threats to genome stability. Mol Cell 46:115-124. CrossRef Medline

Arlotta P, Molyneaux BJ, Chen J, Inoue J, Kominami R, Macklis JD (2005) Neuronal subtype-specific genes that control corticospinal motor neuron development in vivo. Neuron 45:207-221. CrossRef Medline

Barazzuol L, Rickett N, Ju L, Jeggo PA (2015) Low levels of endogenous or $\mathrm{X}$-ray-induced DNA double-strand breaks activate apoptosis in adult neural stem cells. J Cell Sci 128:3597-3606. CrossRef Medline

Barnes DE, Stamp G, Rosewell I, Denzel A, Lindahl T (1998) Targeted disruption of the gene encoding DNA ligase IV leads to lethality in embryonic mice. Curr Biol 8:1395-1398. CrossRef Medline

Bartek J, Lukas C, Lukas J (2004) Checking on DNA damage in S phase. Nat Rev Mol Cell Biol 5:792-804. CrossRef Medline

Barzilai A (2013) The interrelations between malfunctioning DNA damage response (DDR) and the functionality of the neuro-glio-vascular unit. DNA Repair (Amst) 12:543-557. CrossRef Medline

Bedogni F, Hodge RD, Elsen GE, Nelson BR, Daza RA, Beyer RP, Bammler TK, Rubenstein JL, Hevner RF (2010) Tbrl regulates regional and laminar identity of postmitotic neurons in developing neocortex. Proc Nat Acad Sci U S A 107:13129-13134. CrossRef Medline

Bensimon A, Schmidt A, Ziv Y, Elkon R, Wang SY, Chen DJ, Aebersold R Shiloh Y (2010) ATM-dependent and -independent dynamics of the nuclear phosphoproteome after DNA damage. Sci Signal 3:rs3. CrossRef Medline

Brown EJ, Baltimore D (2000) ATR disruption leads to chromosomal fragmentation and early embryonic lethality. Genes Dev 14:397-402. CrossRef Medline

Bulfone A, Martinez S, Marigo V, Campanella M, Basile A, Quaderi N, Gattuso C, Rubenstein JL, Ballabio A (1999) Expression pattern of the Tbr2 (Eomesodermin) gene during mouse and chick brain development. Mech Dev 84:133-138. CrossRef Medline

Buss RR, Sun W, Oppenheim RW (2006) Adaptive roles of programmed 
cell death during nervous system development. Annu Rev Neurosci 29:135. CrossRef Medline

Butts T, Green MJ, Wingate RJ (2014) Development of the cerebellum: simple steps to make a 'little brain.' Development 141:4031-4041. CrossRef

Callén E, Jankovic M, Wong N, Zha S, Chen HT, Difilippantonio S, Di Virgilio M, Heidkamp G, Alt FW, Nussenzweig A, Nussenzweig M (2009) Essential role for DNA-PKcs in DNA double-strand break repair and apoptosis in ATM-deficient lymphocytes. Mol Cell 34:285-297. CrossRef Medline

Chapman JR, Taylor MR, Boulton SJ (2012) Playing the end game: DNA double-strand break repair pathway choice. Mol Cell 47:497-510. CrossRef Medline

Chechlacz M, Vemuri MC, Naegele JR (2001) Role of DNA-dependent protein kinase in neuronal survival. J Neurochem 78:141-154. CrossRef Medline

Davis AJ, Chen DJ (2013) DNA double strand break repair via nonhomologous end-joining. Transl Cancer Res 2:130-143. Medline

de Klein A, Muijtjens M, van Os R, Verhoeven Y, Smit B, Carr AM, Lehmann AR, Hoeijmakers JH (2000) Targeted disruption of the cell-cycle checkpoint gene ATR leads to early embryonic lethality in mice. Curr Biol 10:479-482. CrossRef Medline

Dominguez MH, Ayoub AE, Rakic P (2013) POU-III transcription factors (Brn1, Brn2, and Oct6) influence neurogenesis, molecular identity, and migratory destination of upper-layer cells of the cerebral cortex. Cereb Cortex 23:2632-2643. CrossRef Medline

Douglas P, Gupta S, Morrice N, Meek K, Lees-Miller SP (2005) DNA-PKdependent phosphorylation of Ku70/80 is not required for nonhomologous end joining. DNA Repair (Amst) 4:1006-1018. CrossRef Medline

Englund C, Fink A, Lau C, Pham D, Daza RA, Bulfone A, Kowalczyk T, Hevner RF (2005) Pax6, Tbr2, and Tbr1 are expressed sequentially by radial glia, intermediate progenitor cells, and postmitotic neurons in developing neocortex. J Neurosci 25:247-251. CrossRef Medline

Frank KM, Sharpless NE, Gao Y, Sekiguchi JM, Ferguson DO, Zhu C, Manis JP, Horner J, DePinho RA, Alt FW (2000) DNA ligase IV deficiency in mice leads to defective neurogenesis and embryonic lethality via the p53 pathway. Mol Cell 5:993-1002. CrossRef Medline

Gao Y, Chaudhuri J, Zhu C, Davidson L, Weaver DT, Alt FW (1998a) A targeted DNA-PKcs-null mutation reveals DNA-PK-independent functions for $\mathrm{KU}$ in $\mathrm{V}(\mathrm{D}) \mathrm{J}$ recombination. Immunity 9:367-376. CrossRef Medline

Gao Y, Sun Y, Frank KM, Dikkes P, Fujiwara Y, Seidl KJ, Sekiguchi JM, Rathbun GA, Swat W, Wang J, Bronson RT, Malynn BA, Bryans M, Zhu C, Chaudhuri J, Davidson L, Ferrini R, Stamato T, Orkin SH, Greenberg ME, et al. (1998b) A critical role for DNA end-joining proteins in both lymphogenesis and neurogenesis. Cell 95:891-902. CrossRef Medline

Gatz SA, Ju L, Gruber R, Hoffmann E, Carr AM, Wang ZQ, Liu C, Jeggo PA (2011) Requirement for DNA ligase IV during embryonic neuronal development. J Neurosci 31:10088-10100. CrossRef Medline

Goodarzi AA, Kurka T, Jeggo PA (2011) KAP-1 phosphorylation regulates CHD3 nucleosome remodeling during the DNA double-strand break response. Nat Struct Mol Biol 18:831-839. CrossRef Medline

Goodwin JF, Knudsen KE (2014) Beyond DNA repair: DNA-PK function in cancer. Cancer Discov 4:1126-1139. CrossRef Medline

Gu Y, Sekiguchi J, Gao Y, Dikkes P, Frank K, Ferguson D, Hasty P, Chun J, Alt FW (2000) Defective embryonic neurogenesis in Ku-deficient but not DNA-dependent protein kinase catalytic subunit-deficient mice. Proc Natl Acad Sci U S A 97:2668-2673. CrossRef Medline

Gurley KE, Kemp CJ (2001) Synthetic lethality between mutation in Atm and DNA-PK(cs) during murine embryogenesis. Curr Biol 11:191-194. CrossRef Medline

Herzog KH, Chong MJ, Kapsetaki M, Morgan JI, McKinnon PJ (1998) Requirement for Atm in ionizing radiation-induced cell death in the developing central nervous system. Science 280:1089-1091. CrossRef Medline

Hevner RF, Shi L, Justice N, Hsueh Y, Sheng M, Smiga S, Bulfone A, Goffinet AM, Campagnoni AT, Rubenstein JL (2001) Tbrl regulates differentiation of the preplate and layer 6. Neuron 29:353-366. CrossRef Medline

Hoshino K, Kameyama Y (1988) Developmental-stage-dependent radiosensitivity of neural cells in the ventricular zone of telencephalon in mouse and rat fetuses. Teratology 37:257-262. CrossRef Medline

Hoshino K, Kameyama Y, Inouye M (1991) Split-dose effect of X-irrad- iation on the induction of cell death in the fetal mouse brain. J Radiat Res 32:23-27. CrossRef Medline

Jasin M, Rothstein R (2013) Repair of strand breaks by homologous recombination. Cold Spring Harb Perspect Biol 5:a012740. CrossRef Medline

Jette N, Lees-Miller SP (2015) The DNA-dependent protein kinase: a multifunctional protein kinase with roles in DNA double strand break repair and mitosis. Prog Biophys Mol Biol 117:194-205. CrossRef Medline

Katyal S, Lee Y, Nitiss KC, Downing SM, Li Y, Shimada M, Zhao J, Russell HR, Petrini JH, Nitiss JL, McKinnon PJ (2014) Aberrant topoisomerase-1 DNA lesions are pathogenic in neurodegenerative genome instability syndromes. Nat Neurosci 17:813-821. CrossRef Medline

Lavin MF (2008) Ataxia-telangiectasia: from a rare disorder to a paradigm for cell signalling and cancer. Nat Rev Mol Cell Biol 9:759-769. CrossRef Medline

Lee BS, Gapud EJ, Zhang S, Dorsett Y, Bredemeyer A, George R, Callén E, Daniel JA, Osipovich O, Oltz EM, Bassing CH, Nussenzweig A, LeesMiller S, Hammel M, Chen BP, Sleckman BP (2013) Functional intersection of ATM and DNA-dependent protein kinase catalytic subunit in coding end joining during V(D)J recombination. Mol Cell Biol 33:3568 3579. CrossRef Medline

Lee Y, Barnes DE, Lindahl T, McKinnon PJ (2000) Defective neurogenesis resulting from DNA ligase IV deficiency requires Atm. Genes Dev 14: 2576-2580. CrossRef Medline

Lee Y, Chong MJ, McKinnon PJ (2001) Ataxia telangiectasia mutateddependent apoptosis after genotoxic stress in the developing nervous system is determined by cellular differentiation status. J Neurosci 21: 6687-6693. Medline

Lee Y, Shull ER, Frappart PO, Katyal S, Enriquez-Rios V, Zhao J, Russell HR, Brown EJ, McKinnon PJ (2012) ATR maintains select progenitors during nervous system development. EMBO J 31:177-1189. CrossRef Medline

Li J, Han YR, Plummer MR, Herrup K (2009) Cytoplasmic ATM in neurons modulates synaptic function. Curr Biol 19:2091-2096. CrossRef Medline

Lieber MR (2010) The mechanism of double-strand DNA break repair by the nonhomologous DNA end-joining pathway. Annu Rev Biochem 79: 181-211. CrossRef Medline

Liu J, Naegele JR, Lin SL (2009) The DNA-PK catalytic subunit regulates Bax-mediated excitotoxic cell death by Ku70 phosphorylation. Brain Res 1296:164-175. CrossRef Medline

Madabhushi R, Pan L, Tsai LH (2014) DNA damage and its links to neurodegeneration. Neuron 83:266-282. CrossRef Medline

Marechal A, Zou L (2013) DNA damage sensing by the ATM and ATR kinases. Cold Spring Harb Perspect Biol 5:piia012716. CrossRef Medline

Matsuoka S, Ballif BA, Smogorzewska A, McDonald ER 3rd, Hurov KE, Luo J, Bakalarski CE, Zhao Z, Solimini N, Lerenthal Y, Shiloh Y, Gygi SP, Elledge SJ (2007) ATM and ATR substrate analysis reveals extensive protein networks responsive to DNA damage. Science 316:1160-1166. CrossRef Medline

McKinnon PJ (2012) ATM and the molecular pathogenesis of ataxia telangiectasia. Annu Rev Pathol 7:303-321. CrossRef Medline

McKinnon PJ (2013) Maintaining genome stability in the nervous system. Nat Neurosci 16:1523-1529. CrossRef Medline

Mihalas AB, Elsen GE, Bedogni F, Daza RA, Ramos-Laguna KA, Arnold SJ, Hevner RF (2016) Intermediate progenitor cohorts differentially generate cortical layers and require Tbr2 for timely acquisition of neuronal subtype identity. Cell Rep 16:92-105. CrossRef Medline

Molyneaux BJ, Arlotta P, Menezes JR, Macklis JD (2007) Neuronal subtype specification in the cerebral cortex. Nat Rev Neurosci 8:427-437. CrossRef Medline

Murga M, Bunting S, Montaña MF, Soria R, Mulero F, Cañamero M, Lee Y, McKinnon PJ, Nussenzweig A, Fernandez-Capetillo O (2009) A mouse model of ATR-Seckel shows embryonic replicative stress and accelerated aging. Nat Genet 41:891-898. CrossRef Medline

Nam EA, Cortez D (2011) ATR signalling: more than meeting at the fork. Biochem J 436:527-536. CrossRef Medline

O’Driscoll M, Ruiz-Perez VL, Woods CG, Jeggo PA, Goodship JA (2003) A splicing mutation affecting expression of ataxia-telangiectasia and Rad3related protein (ATR) results in Seckel syndrome. Nat Genet 33:497-501. CrossRef Medline

O'Driscoll M, Gennery AR, Seidel J, Concannon P, Jeggo PA (2004) An overview of three new disorders associated with genetic instability: LIG4 
syndrome, RS-SCID and ATR-Seckel syndrome. DNA Repair (Amst) 3:1227-1235. CrossRef Medline

Oishi K, Aramaki M, Nakajima K (2016) Mutually repressive interaction between Brn1/2 and Rorb contributes to the establishment of neocortical layer 2/3 and layer 4. Proc Natl Acad Sci U S A 113:3371-3376. CrossRef Medline

Orii KE, Lee Y, Kondo N, McKinnon PJ (2006) Selective utilization of nonhomologous end-joining and homologous recombination DNA repair pathways during nervous system development. Proc Natl Acad Sci U S A 103:10017-10022. CrossRef Medline

Paull TT (2015) Mechanisms of ATM activation. Annu Rev Biochem 84: 711-738. CrossRef Medline

Sessa A, Mao CA, Hadjantonakis AK, Klein WH, Broccoli V (2008) Tbr2 directs conversion of radial glia into basal precursors and guides neuronal amplification by indirect neurogenesis in the developing neocortex. Neuron 60:56-69. CrossRef Medline

Shiloh Y, Ziv Y (2013) The ATM protein kinase: regulating the cellular response to genotoxic stress, and more. Nat Rev Mol Cell Biol 14:197-210. CrossRef Medline

Shimada M, Dumitrache LC, Russell HR, McKinnon PJ (2015) Polynucleotide kinase-phosphatase enables neurogenesis via multiple DNA repair pathways to maintain genome stability. EMBO J 34:2465-2480. CrossRef Medline

Shull ER, Lee Y, Nakane H, Stracker TH, Zhao J, Russell HR, Petrini JH, McKinnon PJ (2009) Differential DNA damage signaling accounts for distinct neural apoptotic responses in ATLD and NBS. Genes Dev 23:171180. CrossRef Medline

Spear PC, Erickson CA (2012) Interkinetic nuclear migration: a mysterious process in search of a function. Dev Growth Differ 54:306-316. CrossRef Medline

Stiff T, O’Driscoll M, Rief N, Iwabuchi K, Löbrich M, Jeggo PA (2004) ATM and DNA-PK function redundantly to phosphorylate $\mathrm{H} 2 \mathrm{AX}$ after exposure to ionizing radiation. Cancer Res 64:2390-2396. CrossRef Medline

Stracker TH, Petrini JH (2011) The MRE11 complex: starting from the ends. Nat Rev Mol Cell Biol 12:90-103. CrossRef Medline

Tripathi DN, Zhang J, Jing J, Dere R, Walker CL (2016) A new role for ATM in selective autophagy of peroxisomes (pexophagy). Autophagy 12:711712. CrossRef Medline

van der Burg M, Ijspeert H, Verkaik NS, Turul T, Wiegant WW, MorotomiYano K, Mari PO, Tezcan I, Chen DJ, Zdzienicka MZ, van Dongen JJ, van Gent DC (2009) A DNA-PKcs mutation in a radiosensitive T-B- SCID patient inhibits Artemis activation and nonhomologous end-joining. J Clin Invest 119:91-98. CrossRef Medline

Vemuri MC, Schiller E, Naegele JR (2001) Elevated DNA double strand breaks and apoptosis in the CNS of scid mutant mice. Cell Death Differ 8:245-255. CrossRef Medline

Wong RH, Chang I, Hudak CS, Hyun S, Kwan HY, Sul HS (2009) A role of DNA-PK for the metabolic gene regulation in response to insulin. Cell 136:1056-1072. CrossRef Medline

Woodbine L, Neal JA, Sasi NK, Shimada M, Deem K, Coleman H, Dobyns WB, Ogi T, Meek K, Davies EG, Jeggo PA (2013) PRKDC mutations in a SCID patient with profound neurological abnormalities. J Clin Invest 123:2969-2980. CrossRef Medline

Yamaguchi Y, Miura M (2015) Programmed cell death in neurodevelopment. Dev Cell 32:478-490. CrossRef Medline

Zhou Z, Bruhn C, Wang ZQ (2012) Differential function of NBS1 and ATR in neurogenesis. DNA Repair (Amst) 11:210-221. CrossRef Medline

Ziv Y, Bielopolski D, Galanty Y, Lukas C, Taya Y, Schultz DC, Lukas J, BekkerJensen S, Bartek J, Shiloh Y (2006) Chromatin relaxation in response to DNA double-strand breaks is modulated by a novel ATM- and KAP-1dependent pathway. Nat Cell Biol 8:870-876. CrossRef Medline 